\title{
Academic Law Libraries and Scholarship: Communication, Publishing, and Ranking
}

\author{
DANA NEACSU AND JAMES M. DONOVAN*
}

\section{INTRODUCTION}

The context in which academic libraries operate is fast evolving, and the current COVID pandemic has underscored the new demands on libraries to reinvent themselves and their scholarship role. The library's role has always been focused on scholarly dissemination and preservation, more recently by archiving their faculty work on mirror sites known as academic repositories. Libraries connect scholarship and users by offering the space for users to come and use the archived knowledge. However, if historically their role was to collect and provide secure access to sources, that role is in the midst of radical transformations.

In our age of the Internet, the connection between knowledge and library users has become more complex. First, users have formed attachments to print or digital knowledge according to the type of reading they engage in, moving fluidly from one to the other. In that respect, as James M. Donovan has recently explained, ${ }^{1}$ the library space remains an intrinsic facilitator of a type of academic reading. Second, when

* Dana Neacsu is Librarian and Lecturer-in-Law at Columbia University Law School and Adjunct Faculty in the Environmental Science Department, at Columbia University, Barnard College. James M. Donovan is Library Director and James and Mary Lassiter Associate Professor of Law at University of Kentucky Rosenburg College of Law. The authors would like to acknowledge that the earlier draft presented to the 2019 Boulder Conference headed by Professor and Director of the Law Library at University of Colorado Law School, Susan Nevelow Mart, was also co-authored by Benjamin Keele, Research and Instructional Services Librarian at Indiana University Robert H. McKinney School of Law Indianapolis. We would also like to thank Barnard student Alissa Lampert for creating Appendix 5.

1. See generally James. M. Donovan, Keep the Books on the Shelves: Library Space as Intrinsic Facilitator of the Reading Experience, 46 J. ACAD. LIBRARIANSHIP 1, (2020), https://doi.org/10.1016/j.acalib.2019.102104 (arguing that by studying in book-rich library enviroments individuals can increase their performance on reading comprehension tasks). 
knowledge is accessed digitally, the flow of content becomes decentralized. Instead of expecting their needs to be found in the library, users seek out resources wherever they may be stored, anywhere on the planet. More interestingly, technology enables users to develop a different connection to the digital content, creating it while accessing it, from the mere "likes" or "dislikes" to virtual annotations through reader comments, for instance. Either way, libraries are seeing their passive intermediary role dissipate: even when shelving knowledge, as this article advocates, libraries may choose to become engaged in new ways as active participants in the scholarship enterprise.

After reviewing the background against which these challenges have appeared, we suggest that libraries define for themselves a more active role within scholarship production, which we define to include publication, distribution, access, and the process of scholarship impact assessment. The argument rests on the practical considerations of business organization. Curating the output of faculty scholarship is simply good business for law schools, and many already do it through faculty repositories. Given that foundation, it seems logical for the library, as the institution which already manages those repositories, and which supports the students' law reviews and journals in numerous ways, to step up and manage the full range of scholarship publication. This library management of student-edited scholarship production could cover all its aspects, excluding editorial publication decision and manuscript editing, from training and assisting to gather sources for cite checks, adding journal content to institutional platforms, administering technology services, and advising on copyright.

Another reason for supporting a more active role for libraries in the scholarly enterprise rests on the flaws of the current academic ranking of scholarship. Without human input, no automated system-including the newly-promoted Hein database-can meaningfully contextualize the value of a citation. For instance, only librarians can find the equivalent (if any) of scholarship cited and reviewed in the New Yorker or the New York Review of Books among scholarship cited in another law journal or review article, or calibrate the value of an article citation in a court decision. To the extent there is agreement that quantifying scholarship citation impact requires human expertise, then we argue for librarian expertise.

A more active role for libraries in the scholarship enterprise, especially as publishers, seems only natural. Here, we present the suggestion as a logical outcome of data collected from two surveys about the role that 
libraries already play in this area. ${ }^{2}$ In addition, we use a small sample of citation sources for criminal law scholarship to further buttress our thesis on measuring scholarly impact. ${ }^{3}$ Finally, we suggest that the libraries' active role in scholarship production and communication could be assumed either individually, through a consortium similar to OCLC, which is a global information cooperative founded in 1967 by presidents of colleges and universities in Ohio, ergo, Ohio College Library Center. ${ }^{4}$ An alternative strategy could rely on repository user groups which offer in-house application of collectively-devised standards.

\section{THE CURRENT ROLE OF ACADEMIC LAW LIBRARIES WITHIN SCHOLARSHIP PRODUCTION}

\section{A. Overview}

For decades, the library's role was intertwined with its space. In other words, the value of a library's services was determined by the value of its open shelves and the shelved information accessed by students, faculty, and other scholars. Law libraries have evaluated and acquired print resources since their inception, and more recently they evaluate digital resources, including database aggregators like HeinOnline, Westlaw and Lexis Advance, submission and editing products such as Scholastica and ExpressO, and distribution repositories such as Digital Commons and LawArXiv.

But now, as information becomes increasingly available in digital format, academic libraries are transforming into study environments. ${ }^{5}$ The value previously offered by the open shelves is being replaced, for better or worse, by a variety of other library services. ${ }^{6}$ Some of the "replacement" services have now become old news. For instance, it is within the job description of most public services academic law librarians

2. See infra, Appendix $1 \& 3$.

3. See infra, Appendix $4 \& 5$.

4. See OCLC Company Profile, Dun \& BRADSTREET, https://perma.cc/V2YQ-TQ6X (last visited Sept. 29, 2020).

5. See, e.g., Coen Wilders, Predicting the Role of Library Bookshelves in 2025, 43 J. ACAD. LIBRARIANSHIP 384, 384 (2017).

6. Id. 
to teach legal and digital literacy in various forms. ${ }^{7}$ However, other changes have still to occur on a similar mass scale. Not all libraries see their role within scholarship publication, distribution, access, and archiving beyond the previous library role of "knowledge shelving."

The opportunity for law libraries to assume a higher profile in the production and promotion of faculty scholarship emerges from the unique disciplinary nature of legal scholarship. First, as Ian Gallacher has already noticed, the object of legal scholarship is the law, whose impenetrable language comes, or should come, with a scholarly duty to decipher it and make it accessible to the public through open sources. ${ }^{8}$ Law libraries have long suported this process with various degrees of success. Moreover, if in other academic areas faculty evaluations, promotion, and tenure depend on scholarship published in the peer-reviewed journals that are the realm of commercial publishers, within the legal academy this is not the case. The primary venue for legal scholarship is the student-edited law review:

Numbering near one thousand titles and growing, more law journals than ever are now being published by U.S. law schools. Most of these journals are edited by students, and the fact that more journals are being established indicates there is demand from students for opportunities to work on a journal or from professors for publication venues. Editors and authors share a common goal to produce legal scholarship that is read, cited, and influential. $^{10}$

This proximity of scholarly production within the law school itself creates new opportunities for law libraries. Here we propose that libraries take over administering and managing the production process because it makes sense institutionally. Libraries already do it, and it fits with the

7. See, e.g., Genevieve B. Tung, Collaboration Between Legal Writing Faculty and Law Librarians: Two Surveys, 23 Legal Writing: J. Legal Writing InST. 215, 215-16 (2019).

8. Ian Gallacher, "Aux Armes, Citoyens!:" Time for Law Schools to Lead the Movement for Free and Open Access to the Law, 40 U. ToL. L. REv. 1, 4-5 (2008).

9. See Dana Neacsu, Google, Legal Citations, and Electronic Fickleness: Legal scholarship in the Digital Environment, Colum. U. LIBRS. (2007) https://doi.org/10.7916/D87M0DR7; See generally Thomas L. Fowler, Law Reviews and Their Relevance to Modern Legal Problems, 24 CAMPBELl L. REV. 47 (2001) (explaining the transformation of legal scholarship included in student-edited law review articles).

10. Benjamin J. Keele \& Michelle Pearse, How Librarians Can Help Improve Law Journal Publishing, 104 L. LIBR. J. 383, 383 (2012). 
needs to improve the academic scholarship impact process, as shown below.

The vast majority of accredited law schools in the United States publish a student-edited law review containing scholarly writing about recent court decisions, unresolved issues of law, and other topics of interest to the legal community. In addition, most also publish specialized journals offering the same type of content but within a narrow area of topical interest such as business law, criminal law, family law, sports and law, and the like. Michael I. Swygert and Jon W. Bruc described how the tradition started. ${ }^{11}$ Begun a century ago by law students as an academic experiment, law-student journals have achieved such a prominent and influential position in the legal profession, numbering near one thousand titles as of 2012,12 that, quantitatively, articles chosen and edited by students represent the vast majority of scholarship in most areas of American legal study.

This process is not employed in any other academic discipline, a reality that results in two important consequences. First, unlike all other scholarly journals whose content is selected through a panel of peer referees, law journals and reviews have law students decide what constitutes legal scholarship. Second, although the production of both law and non-law scholarly journals relies completely upon the voluntary participation of faculty experts, only non-law scholarship is sold back at astronomical prices to the universities employing those very authors, generating billions of dollars in profits. ${ }^{13}$

The second point is striking and needs further explanation because it offers a window of opportunity for libraries to actively participate in publishing scholarship. Scholars from all disciplines have always published their work for the benefit of sharing it with their peers and for employment promotion, such as tenure. While scholars have their work published freely in a specific journal without being directly compensated

11. Michael I. Swygert \& Jon W. Bruce, The Historical Origins, Founding, and Early Development of Student-Edited Law Reviews, 36 Hastings L.J. 739, 739-40 (1985); see also David B. McGinty, Writing for a Student-Edited U.S. Law Review: A Guide for Non-U.S. and ESL Legal Scholars, 7 CUNY L. REV. 39, 41-43 (2004).

12. See Swygert \& Bruce, supra note 11, at 739-40; see generally McGinty, supra note 11, at $41-43$.

13. See Kate Murphy, Should All Research Papers Be Free? The New York Times (March 12 , 2016) available at https://www.nytimes.com/2016/03/13/opinion/sunday/should-allresearch-papers-be-free.html (last accessed September 16, 2020). 
in royalties, for instance, most non-law journals are sold twice to universities: once as an independent title and a second time bundled by various aggregators. Today, this is a multi-billion-dollar-industry paid for by academic libraries through their acquisition budgets. ${ }^{14}$ While prosperous, the model does not benefit individual scientists or even many individual journals. Most benefits fall to the largest aggregators, like Elsevier, Taylor \& Francis, Springer, and Wiley, which typically have profit margins of over thirty percent. ${ }^{15}$ For example, while most successful publications can expect to realize between twelve and fifteen percent, Elsevier, which recently added Digital Commons and SSRN to its portfolio, regularly reports a profit of 36 percent. ${ }^{16}$

General libraries pay annual subscription fees ranging from $\$ 2,000$ to $\$ 35,000$ per title when they do not buy subscriptions of bundled titles, which can cost upwards of a million dollars for each publisher. ${ }^{17}$ While some may regard the aggregators" high price as "justified" because some perceive them as "curators of research," 18 that libraries must accept this situation has become questionable, especially under the current budgetary cuts imposed by the COVID pandemic. Even before this cataclysm of sorts, several major library systems, such as the University of California ${ }^{19}$ and the Max Planck Institute, ${ }^{20}$ have refused to renew contracts with Elsevier, suggesting tolerance of the exorbitant status quo may be wearing thin.

Student-edited publications, as their title suggests, do not typically contain a peer review selection process. Further reducing their production

14. Id.

15. Id.

16. Stephen Buryani, Is the Staggeringly Profitable Business of Scientific Publishing Bad for Science?, THE GUARDIAN (June 27, 2017), https://www.theguardian.com/science/ 2017/jun/27/profitable-business-scientific-publishing-bad-for-science.

17 Lindsay McKenzie, 'Big Deal' Cancellations Gain Momentum, Inside HigHer ED (May 8, 2018), https://www.insidehighered.com/news/2018/05/08/more-institutions-consider-endingtheir-big-deals-publishers.

18. Pat McNee, Revolution in Academia: Copyright and Open Access, WRITERS AND Editors: PAT MCNeEs's Blog, (Nov. 29, 2015), http://www.writersandeditors.com/ blog/posts/33304.

19. Lindsay McKenzie, UC Drops Elsevier, InSIDE HigheR ED (Mar. 1, 2019), https://www.insidehighered.com/news/2019/03/01/university-california-cancels-deal-elsevierafter-months-negotiations.

20. Max Planck Society Discontinues Agreement with Elsevier; Stands Firm with Projekt DEAL Negotiations, MAX PLANCK DigiTAL LiBR., https://www.mpdl.mpg.de/en/505 (last visited Aug. 15, 2020). 
costs are the lack of illustrations and hard-to-execute graphs. Most operate on small budgets with little financial benefit to the sponsoring schools, and rely on help from their schools' libraries with the prepublishing process.

Thus, law scholarship production, by the nature of its communication through student-edited journals, offers opportunities for law school libraries to become more deeply involved in the generation of scholarship in ways that are not available to other academic departments. Furthermore, we can do it alone, incorporating the existing institutional digital repositories, or Academic Commons, built through the open access movement, or through library consortia. Although in uncharted waters in this area, law libraries have already a foundation of digital activism to build upon.

\section{B. The impact of open access for the libraries' active role in the scholarship enterprise}

The range of library integration into the scholarship enterprise has been cemented in the digital age in many areas. For instance, scholars and librarians have already been working to develop "open access publishing" as an alternative to traditional print publishing. ${ }^{21}$ SPARC, the Scholarly Publishing and Academic Resources Coalition, ${ }^{22}$ works to enable the "open sharing of research outputs and educational materials in order to democratize access to knowledge, accelerate discovery, and increase the return on our investment in research and education." 23

According to SPARC, "open access" means "the free, immediate, online availability of research articles combined with the rights to use these articles fully in the digital environment." 24 These are the rights that take advantage of the electronic format of the content. In other words,

21. For more on this issue, see generally Simon Canick, Library Services for the SelfInterested Law School: Enhancing the Visibility of Faculty Scholarship, 105 LAW LIBR. J. 175 (2013).

22. SPARC, Open Access, https://sparcopen.org/open-access/ (last visited Aug. 15, 2020).

23. SPARC, Who We Are, https://sparcopen.org/who-we-are/ (last visited Aug. 15, 2020).

24. SPARC, supra note 22; see also James M. Donovan \& Carol A. Watson, Citation Advantage of Open Access Legal Scholarship, 103 LAW LIBR. J. 553, 557 (2011) (quoting SPARC's description of the relevant rights as those permitting "any user to read, download, copy, distribute, print, search or link to the full text of these articles, crawl them for indexing, pass them as data to software or use them for any other lawful purpose."). 
open access is more than a novel means of transporting rights-limited print content from one user to another; sui generis applications that are possible only in that environment are also to be permitted. However, as Donovan and Watson explain, open access does not imply the surrender of all significant rights by the copyright holder. ${ }^{25}$ Perhaps thinking about open access as the much needed modern update for the communication of research in the age of the Internet to accelerate further research and scholarship production is better.

The open access movement has had a slow progression in the legal realm:

\begin{abstract}
Although a handful of law journals published free online versions of their journals as early as [1996], most have relied on a combination of conventional print publishing and making their contents available, for a royalty payment, to commercial legal databases Lexis and Westlaw. In the 1990s, a few legal scholars posted preprints of their articles on their personal websites, and in 1996, Pitt Law School launched Jurist, which collected links to law professors' online archives of their own work. In 1995, the Social Science Research Network (SSRN) launched the Legal Scholarship Network, a commercial online depository for legal scholarship that archived law journal drafts and preprints at no charge and made them available to libraries and universities for a modest subscription fee. SSRN now makes the text of all of its abstracts and most of its papers available to individuals for personal non-commercial use at no charge. In 1999, academics set up the Berkeley Electronic Press (Bepress) to compete with SSRN. Bepress offers electronic law journals and archived legal research under what it describes as a "quasi-open access policy." Legal scholars' participation in open access archives is increasing steadily, but we have so far seen little movement toward open access journal publishing. In 2005, the Creative Commons launched an open access law publishing project in which it sought to persuade law journals to adopt open access publishing principles. So far [2006], it has managed to persuade only twenty-eight U.S. law journals to sign on. ${ }^{26}$
\end{abstract}

This situation has changed in the last ten years. The list of hundreds of law journal titles available on Bepress's Digital Commons platform alone

25. Donovan \& Watson, supra note 24, at 557.

26. Jessica D. Litman, The Economics of Open Access Law Publishing, 10 LEWIS \& CLARK L. REV. 779, 784-85 (2006). 
is both extensive and impressive. ${ }^{27}$ The migration of law publications to open access platforms has most typically been accomplished in cooperation with the law library, which often has general oversight of the institutional electronic repository. ${ }^{28}$

With over ten years of experience, libraries are today comfortable managing their faculty scholarship republished into the Academic Commons, which often function as open access mirror sites of articles previously published in student-edited journals. Once cutting edge, this role is today a far cry from the greater work we can achieve institutionally. Libraries, faced with cultural and environmental changes, are best equipped to assume a leading role in the production, preservation, and impact-measurement of legal scholarship, as the data reported from two academic law libraries surveys shows (Section 3).

\section{New Library Role in Scholarly Communication: Overseeing Academic Scholarship Impact Ranking}

To the extent that this Article argues that academic law libraries should assume a higher profile in the production of scholarship, it continues the thesis presented by Keele and Pearse to encourage academic law libraries to broaden their roles in supporting law review publication and increase the visibility and discoverability of these journals in both the long and the short term. ${ }^{29}$ Their argument goes further than the Durham Statement on Open Access to Legal Scholarship, which in 2009 urged law schools merely to "commit to keeping a repository of the scholarship published at the school in a stable, open, digital format." 30

Recent developments push forward the need to make faculty scholarship available to readers in hopes of increasing its impact. Although libraries have long played a critical role in the collection and preservation of faculty scholarship, the new environment imposes additional responsibilities to make the writings more visible. The most

27. Browse Law Reviews by Title, L. Rev. Commons (last visited Aug. 15, 2020) https://lawreviewcommons.com/peer_review_list.html.

28. Keele \& Pearse, supra note 10, at 384 .

29. Id.

30. Durham Statement on Open Access to Legal Scholarship, available at https://cyber.harvard.edu/publications/durhamstatement (last visited September 16, 2020). 
significant of these recent pressures concerns the effort to measure the intellectual impact of each article.

There exists a wide range of options for measuring scholarly impact. Publication venue (journal impact factor), author (SSRN ranking, hindex), and item (download counts, citation counts) are among the most common variables, and have already been implemented. Much in the way of institutional and personal prestige depend on perceptions of scholarly preeminence. Because libraries are already entwined with the dissemination of intellectual products, the library is a natural place to begin when organizations seek to improve visibility and citations.

Until this year, the U.S. News and World Report ranked the 192 law schools fully accredited by the American Bar Association (A.B.A.) on a weighted average of twelve measures of quality. ${ }^{31}$ This year, the U.S.

31. Robert Morse, Kenneth Hines \& Elizabeth Martin, Methodology: 2020 Best Law Schools Rankings, U.S. NEWS \& WORLD REP., (Mar. 28, 2019, 2:04 PM), https://www.usnews.com/education/best-graduate-schools/articles/law-schools-methodology

1. Peer assessment score (0.25): In fall 2018, law school deans, deans of academic affairs, chairs of faculty appointments and the most recently tenured faculty members were asked to rate programs on a scale from marginal (1) to outstanding (5). Those individuals who did not know enough about a school to evaluate it fairly were asked to mark "don't know."

2. Assessment score by lawyers and judges (0.15): In fall 2018, as in previous years, legal professionals - including the hiring partners of law firms, practicing attorneys and judges - were asked to rate programs on a scale from 1 (marginal) to 5 (outstanding). Those individuals who did not know enough about a school to evaluate it fairly were asked to mark "don't know." The law schools provided U.S. News with the names of those surveyed. A school's score is the average of all the respondents who rated it in the three most recent years of survey results. Responses of "don't know" counted neither for nor against a school.

3. Selectivity (weighted by 0.25 )

4. Median LSAT and GRE scores (0.125): These are the combined median scores on the Law School Admission Test of all 2018 full-time and part-time entrants to the J.D. program.

5. Median undergraduate GPA (0.10): This is the combined median undergraduate GPA of all the 2018 full-time and part-time entrants to the J.D. program.

6. Acceptance rate $(0.025)$ : This is the combined proportion of applicants to both the full-time and part-time J.D. programs who were accepted for the 2018 entering class.

7. Placement Success (weighted by 0.20 ). Success is determined by calculating employment rates for 2017 graduates at graduation ( 0.04 weight $)$ and 10 months after (0.14 weight), as well as the bar passage rate, explained below. 
News will launch a different ranking of law schools to complement the first. The scholarly impact ranking will list schools according to the research productivity of faculties and the number of citations their law professors' scholarship generates. ${ }^{32}$ The citation metrics of this new rankings formula will incorporate HeinOnline citation data.

Derek T. Muller, writing on his blog concerning this project, noted that "this isn't a remarkable proposition. In the first Maclean's ranking of Canadian law schools in 2007, Professor Brian Leiter helped pioneer a rankings system that included faculty citations. Every few years, a ranking of law school faculty by Professor Greg Sisk, building off Professor Leiter's method, is released." ${ }^{33}$

The method Muller mentions ${ }^{34}$ is the Sisk-Leiter "Scholarly Impact Score" which is calculated from the mean and the median of total law journal citations over the past five years to the work of tenured faculty members. In addition to the mean, median, and weighted score, the SiskLeiter listing mentions the tenured law faculty members at each school with the ten highest individual citation counts. ${ }^{35}$

8. Bar passage rate (0.02): This is the ratio of the bar passage rate of a school's 2017 graduating class to that jurisdiction's overall state bar passage rate for first-time testtakers in winter 2017 and summer 2017.

9. Faculty Resources (weighted by 0.15 )

10. Expenditures per student: This is the average expenditures per student for the 2017 and 2018 fiscal years. The average instruction, library and supporting services (0.0975) are measured, as are all other items, including financial aid (0.015).

11. Student-faculty ratio (0.03): This is the ratio of law school students to law school faculty members for 2018. The definition that U.S. News uses is a modified version of the Common Data Set's student-to-faculty ratio definition, a standard used throughout higher education based on the ratio of full-time equivalent students to fulltime equivalent faculty.

12. Library resources $(0.0075)$ : This is the total number of volumes and titles in the school's law library at the end of the 2018 fiscal year.

32. See Karen Sloan, U.S. News to Launch New Way to Rank Law Schools, Law.COM (Feb. 14, 2019, 12:34 PM), https://www.law.com/2019/02/14/u-s-news-to-launch-new-way-to-ranklaw-schools/?slreturn=20190231152317.

33. Derek T. Muller, Will Goodhart's Law come to USNWR's Hein-based Citation Metrics?, EXCESS OF DEMOCRACY (Feb. 13, 2019), http://excessofdemocracy.com/blog/2019/2/willgoodharts-law-come-to-usnwrs-hein-based-citation-metrics.

34. See Gregory C. Sisk, Nicole Catlin, Katherine Veenis \& Nicole Zeman, Scholarly Impact of Law School Faculties in 2018: Updating the Leiter Score Ranking for the Top Third, 15 U. ST. ThOMAs L.J. 95, 112-13 (2018).

35. See id. at 113. 
The Sisk-Leiter ranking when compared to the current, peer-oriented, ranking will not affect the top ten, which have the most scholarly impact to start with, suggesting that citation ranking is gathering momentum in part because "much of what is currently contained in the rankings is immovable peer reputation based on the distant past." ${ }^{36}$ Little will change for " $[\mathrm{t}]$ he law faculties at Yale, Harvard, Chicago, New York University, and Columbia [because they] rank in the top five for Scholarly Impact. The other schools rounding out the top ten are Stanford, the University of California-Berkeley, Duke, Pennsylvania, and Vanderbilt." ${ }^{37}$

As such, the following results were only to be expected: "The most dramatic rises in the 2018 Scholarly Impact Ranking were by four schools that climbed 16 ordinal positions: Kansas (to \#48), USC (to \#23), the University of St. Thomas (Minnesota) (to \#23), and William \& Mary (to \#28)." 38

The effort to quantify scholarly significance is generally thought to be worthwhile because it tracks well with how academics evaluate their own professional worth. ${ }^{39}$ Brian Leiter explains, however, that despite some obvious limitations, "[c]itations to faculty scholarship in law journals is [sic], of course, only one metric of scholarly distinction and

36. Robert Anderson, Some Preliminary Contrarian Thoughts on the US News Proposal to Rank Based on Scholarly Impact, WiTnESSETH: L., DEALS \& DATA, (Feb. 14, 2019) https://witnesseth.typepad.com/blog/2019/02/us-news-to-rank-based-on-scholarlyimpact.htmlitnesseth.typepad.com/blog/2019/02/us-news-to-rank-based-on-scholarlyimpact.html.

37. Sisk et al., supra note 34 at 95.

38. Id. ("In addition, two schools rose by 10 spots: Florida State (to \#29) and San Francisco (to \#54). Several law faculties achieve a Scholarly Impact Ranking in 2018 well above the law school rankings reported by U.S. News for 2019: Vanderbilt (at \#10) repeats its appearance within the top ten for Scholarly Impact, but is ranked lower by U.S. News (at \#17). Among the top ranked schools, the University of California-Irvine experiences the greatest incongruity, ranking just outside the top ten (\#12) for Scholarly Impact, but holding a U.S. News ranking nine ordinal places lower (at \#21). In the Scholarly Impact top 25, George Mason rises slightly (to \#19), but remains under-valued in U.S. News (at \#41). George Washington stands at \#16 in the Scholarly Impact Ranking, while falling just inside the top 25 (at \#24) in U.S. News").

39. Meredith T. Niles et al., Why We Publish Where We Do: Faculty Publishing Values and Their Relationship to Review, Promotion and Tenure Expectations, 15(3) PLOS ONE e0228914 (Mar. 11, 2020), https://doi.org/10.1371/journal.pone.0228914. 
accomplishment. Still, it is a useful check on uninformed opinions, and tracks rather well the actual scholarly output of different schools." ${ }^{40}$

The proposed new citation indicator by U.S. News will be based on the HeinOnline library of publications, a decision that some critics have questioned. ${ }^{41}$ The Hein holdings are far from comprehensive, and the tagging necessary for reliable citation discovery is largely untested. ${ }^{42}$ However, the arguable virtue of the proposed reliance on Hein is that the scores are automatically generated by the vendor, with no possible wiggle room or gaming by either the schools or the magazine ${ }^{43}$. Any other approach-using Westlaw and Lexis to generate Leiter scores, for example-will depend on judgment calls which are beyond the ability of U.S. News to collect. That alternative would require that the magazine rely on schools to self-report, which could be a more treacherous route to go down.

Thus, proponents argue that despite its flaws, the plan has the virtue of treating all schools uniformly. ${ }^{44}$ All of the disadvantages rightly attributed to Hein would not uniquely disadvantage one school over the other. ${ }^{45}$ Admittedly, interdisciplinary work which often appears outside of law reviews and is cited by publications other than law reviews, would be overlooked. Even though the new impact score may thus underreport an individual's absolute impact, it might not misrepresent the school's relative collective scholarly impact. ${ }^{46}$ There is no data yet to support concerns that because of the sway that U.S. News holds, it may even reduce the incentives for interdisciplinary work, ${ }^{47}$ or discourage hiring faculty that produce scholarship in niche subjects. Jeff Sovern cogently explains:

To be more concrete, imagine that a law school is hiring a new professor and has two candidates. One candidate writes about criminal law and the

40. Brian Leiter, Top 50 Law Schools Based on Scholarly Impact, 2018, BRIAN LEITER's L. ScH. REP., (Aug. 13, 2018), https://leiterlawschool.typepad.com/leiter/2018/08/top-50-lawschools-based-on-scholarly-impact-2018.html\#.

41. Morse et al., supra note 31 .

42. Id.

43. Id.

44. See, e.g., Leiter, supra note 40.

45. Id.

46. Morse et al., supra note 31.

47. See Anderson, supra note 36. 
other writes about consumer law. The law school wants to maximize its ranking, and so wants to hire the candidate whose work will be cited more. The universe of people writing scholarly articles about criminal law is much larger than the universe of professors writing about consumer law, and so, all other things being equal, the criminal law professor is likely to rack up more citations and so help with the school's ranking more. How do we know more people write about criminal law? I did a search for "consumer law" on SSRN and got 637 hits. "Criminal law" by contrast elicited 7,867 hits, or more than a dozen times as many. Every law school offers criminal law courses, probably all have a full-time professor teaching in the area, and many have one or more professors writing in the area. But as of 2014, only about a third of law schools had a consumer law course of one sort or another (yes, I need to update that), and many of the courses were taught by adjuncts who have a day job and so are unlikely to find time to write about consumer law. Fewer professors writing in an area means fewer people likely to cite your work. And so that means hiring the consumer law scholar could hurt your ranking as compared to hiring the criminal law professor. It also means that those seeking to become law professors should write in widely-taught areas to make themselves more attractive to law schools. ${ }^{48}$

Assuming that all law schools hire at least one criminal law professor, we recently attempted to come up with objective metrics to measure the scholarship impact of eight criminal law professors. We looked at their entire body of work, as presented in their CVs. Then, we counted the citations offered by three aggregators: Hein, Westlaw's KeyCite, and Lexis' Shepard's. To these citation data we also added download statistics from SSRN and from the authors' institutional open access repository, named here, "Academic Commons." SSRN abstract views, which do not always lead to a full download, were also recorded. ${ }^{49}$

Quantitatively, we noticed that any automated system necessarily favors authors with academic work spanning a longer period of time because they have had the opportunity to accumulate more downloads and more citations. Additionally, law review articles were more cited than

48. Jeff Sovern, How the New US News Scholarly Impact Ranking Could Hurt Niche Subjects, Like Consumer Law, CONSUMER L. \& POL'Y Blog, (Mar. 7, 2019), https://pubcit.typepad.com/clpblog/2019/03/how-the-new-us-news-scholarly-impact-rankingcould-hurt-niche-subjects-like-consumer-law.html.

49. See infra, Appendix 4 \& 5 . 
books, or book chapters. Although three of the eight authors had no institutional repository presence, of those who did, four of the five had more downloads from the Academic Commons than from SSRN. Hein citation counts were rarely equal to either KeyCite or Shepard's citation counts, and only in six instances (out of 111) were the Hein counts higher than either KeyCite's or Shepard's.' In all other instances, the difference is substantially less, sometimes by a dozen citations. ${ }^{50}$

KeyCite had the most citations between the three for all but Scholar $5 .{ }^{51}$ Interestingly, without attempting to control for time, we found no meaningful correlation between the rank of a journal and the frequency of that article's citation ( $r$ scores ranged from 0.11 for KeyCite to 0.15 for Shepard's). For instance, a 2016 article in the Iowa Law Review (Washington and Lee Law Journal Ranking Combined Score ${ }^{52}$ of 58.4) is more cited than one published the same year in the Columbia Law Review (CLR) (ranked 72.4) by the same scholar (Scholar 4) within the same subject matter. Contrarily, a 2006 Fordham Law Review article (ranked 60.5) was cited more than a work by the same scholar (Scholar 5) published two years earlier in the University of Cincinnati Law Review, which is ranked only $12.6 .{ }^{53}$ Finally, the CLR article produces one of the few instances where the number of citations within Hein, Westlaw and Lexis, are all the same.

Thus, if citation counting were to be somehow automated and aggregated, mere citation results are quite often hard to read meaningfully. Westlaw and Lexis produced different results. Hein's coverage proved less comprehensive than Westlaw and Lexis journal coverage. More daunting is the realization that mere citation numbers tell only half of the story of scholarship impact, and while it may seem that it penalizes all authors in the same way, that is far from true. Each citation has its own context, and librarians are best equipped to offer a reliable answer about their meaning, in terms of the depth of who cited what where. In fact, a library staff member with proper training can easily identify and explain these differences.

50. Id.

51. See infra, Appendix 5.

52. See W\&L Law Journal Rankings, WASH. \& LEE L., https://managementtools4.wlu.edu/ LawJournals/. (the Washington and Lee Law Journal Combined Score aggregates ranks for impact factor, article cites, currency factor, and case cites).

53. Id. 
While libraries manage open access for faculty scholarship repositories, and arguably have the means to check and evaluate scholarship citation, they are also becoming best situated to administer journal-based scholarship publication. While not all are there yet, many of us have already assumed that role. Next we argue for a national change in institutional library roles.

\section{The Library's Role in Scholarship Publication: Survey Descriptions of Current Practices}

To better understand the possibilities for libraries becoming more integrated into the legal scholarly communications system, we thought it useful to have a sense of the status quo. For that we examined two sets of data.

\section{a. AALL Law Repositories Caucus Education Committee}

The AALL Law Repositories Caucus created a survey to gain and share information about the operations and practices of law repositories who have created mirror sites for their faculty's scholarship, previously published elsewhere.

The AALL survey was open from April 16 to May 22, 2019 and received seventy-nine total responses from seventy-one different law libraries. Duplicate responses from the same library were removed from the data set. For each question on the survey, percentages and other calculations reflect only the responses to that particular question, ignoring respondents who skipped the question.

The AALL Survey asked seventeen questions organized in four sections: (1) the law library name; (2) faculty scholarship; (3) studentedited journals, and (4) library staff allocated to building repositories. Section 3, covering the archiving of scholarship published in studentedited journals, asked:

Q3.2 - When do you add new journal issues to your repository? (If you support journals that follow different practices, please select all that apply). Thirty-six libraries $(60 \%)$ responded "on publication", twentyfour $(40 \%)$ sometime after publication, while only eleven institutions or $18 \%$ of the polled libraries showed no interest in adding journalpublished scholarship to their digital repositories. 
Another relevant question was Q3.4 - How are new journal issues added to your repository? (select all that apply). Interestingly, most libraries-forty-eight libraries $(67.60 \%)$ - used their own staff to upload journal content to their repository, and only eighteen libraries used student staff. When the library used their own employees, they sometimes relied on non-librarians, or paraprofessionals, to do this work.

The AALL survey thus shows that a substantial number of libraries (60) are already involved in supporting journal publishing at levels that we consider "publishing" in this paper, creating an opening to promote a more active library role in this area. Additionally, the answers to question Q4.6 - What department(s) within your library contribute staff time to your repository? - showed that repository work is distributed among all library departments, from technical services to reference.

\section{b. SurveyMonkey questionnaire}

To supplement the AALL survey responses, the authors distributed an eight-query questionnaire using SurveyMonkey.

The survey link was sent to a listserv of all law library directors. While the listserv includes present and retired law library directors from both ABA-accredited U.S. law schools and Canadian law schools, it is reasonable to interpret the forty-six answers received as representing about twenty-five percent of all 193 A.B.A. accredited law schools.

The covering email sent to the academic law library directors explained that the survey contained a few brief questions to help its authors learn how libraries were responding to new pressures relating to faculty scholarship, and what practices they had adopted to increase its visibility and impact. The goal was further explained as the identification of helpful trends. Respondents were encouraged to share their thoughts on how they had reacted to these demands, and the direction in which they were taking their libraries to move in the future.

All the questions were clear about their data-gathering intent. The first question asked about the types of law school library support for the publication of the law school's student-edited journals. We identified the forms of possible library involvement and asked for a yes or no answer, while we also offered the chance for explaining other unidentified services the library offered, under the rubric, "other."

We discovered that almost all respondents offered formal training to large groups and/or to individual students, $97.67 \%$, or forty-two 
responding law libraries. Thirty-two libraries, or $74.42 \%$, helped journals gather sources for citation verification and/or formatting citations. Interestingly, more than half of the respondents, $51.16 \%$, or twenty-two libraries, added journal content to institutional platforms (for example, institutional repositories and school websites). The same number of libraries administered technology services, such as Perma.cc and Scholastica. Some libraries also provide copyright advising, and others offer a slew of other services with various degrees of connection to our underlying concern about library-related publishing-support services. Only six libraries, or $13.95 \%$ of respondents, added journal content to research platforms such as Westlaw, Lexis, HeinOnline, and JSTOR, suggesting that some libraries view administering ingest of journal content to for-profit aggregators as an appropriate part of the distribution service, alongside open access support. The fact that most libraries do not add content to fee-based platforms, however, may be a sign that a collaboration between libraries and fee-based databases could be viewed as a capitulation of our leadership in this area, as shown in Appendix 2.

The fourth question asked whether libraries electronically archive (actively collect and retain indefinitely) the scholarship published by the law school student-edited journals? Twenty-five libraries responded yes, marking 54.35\% of the collected answers, as shown in Appendix 2.

The fifth question asked about the platforms used by the respondents engaged in content publication. Interestingly, only twenty-seven library directors $(\sim 59 \%)$ answered that question. Most indicated that they used Digital Commons.

The sixth question asked about the access-focused services the library provided once it archived the journal material. For instance, inter alia, we were interested to know whether the content was available to nonaffiliates and whether it was locatable through various search engines. As with the other more technical questions, only twenty-seven directors answered. Optimistically, the majority of the twenty-seven respondents provided these services, as shown in Appendix 2.

However, only one third of the respondents promoted the archived material in search engine results lists. Positively, because six libraries explained that the search engine promotion was achieved in other ways, we can infer that libraries, to the extent that they archive journalpublished material, are interested in making it freely available to all, and easily accessible. Similarly, the technicality of the question might be the cause for more positive answers. 
Finally, worth noting is the finding from the seventh question. Only $14.2 \%$ of responses indicated libraries captured and archived content published in law journal online supplements. This difference is interesting because it offers a window into understanding the hierarchy of law scholarship production, with articles published in print issues being much more likely to be captured and saved than articles in online supplements, which are thus viewed as having more ephemeral significance. Relatedly, only two libraries archive faculty blogs.

These results suggest the following tentative interpretations. Only about twelve percent of the current academic law library leadership believes that there is an institutional role for libraries in legal scholarship publication. They can serve as a resource and role model to encourage all law libraries to start archiving their law student-edited journals starting with the first issue, using search engine-indexed platforms available to all, including non-affiliates. We are witnessing times of change. Institutionally, this is the time when we can create an expanded space for ourselves, one that builds legitimately upon work the library already does, rather than casting about to find any new task to remain "relevant." Within the new scholarly ecosystem, as the answers to the survey questions show, we already do much for the publication of the studentedited journals. Providing the platforms and the access to those platforms in a manner that is integral to the production workflow rather than tacked on at the end, is the logical next step for us. ${ }^{54}$ The following section looks ahead from this promising present to how law libraries can further actively shape their future.

\section{Incentive to Enter and Control Scholarship Publication and the Ways to Achieve it}

As the data obtained from the AALL survey showed, a substantial number of libraries already support student-edited journals by offering a large array of services, including those described by our definition of the library's publishing role, such as that of platform support and archival,

54. Although outside the scope of the present article, one relevant aspect of that work will be oversight of administrative budgets. For a look at cost estimates for OA journals, see generally, Daniel S. Katz et al, Cost Models for Running an Online Open Journal, J. OPEN SOFTWARE BLOG, (June 4, 2019), http://blog.joss.theoj.org/2019/06/cost-models-for-runningan-online-open-journal. 
indexing and/or search engine enhancement. As Section 4 of the AALL Survey shows, most of the staffing for journal support is provided by library employees, whose services include:

- training student authors on how to post to SSRN, claim/create author profiles (Hein, Google Scholar, ORCID);

- training students on how to perform repository uploading;

- adding digital object identifiers to articles added to repository;

- providing usage statistics on readership through the repository;

- working with students to move their journal website to the library

repository;

- setting up journal pages;

- adding metadata; and

- explaining to student editors the benefits of open access.

All these services and more are currently available from librarians. Fifty-seven out of fifty-eight respondents to the question on staffing reported using non-librarian library employees for repository tasks. Those responses averaged 8.2 hours per week. ${ }^{55}$ Fifteen out of fifty-eight respondents reported spending exactly one hour per week, which suggest that some of these responses may have reported the number of librarians, rather than the number of hours. However allocated, this essential work is already provided by libraries, which makes them best situated to take over journal publishing as shown in Appendix 2.

\section{a. Each Law Library Can Publish Its School's Journals}

The data obtained from both surveys, while certainly incomplete, suggests that libraries are already involved in the journal publication enterprise far more than most would imagine. The entire section on journals in the AALL survey, as shown in Appendix 3, indicates that library management has been able to both allocate funds and attract the staff possessing both the expertise and the desire to help steer this new layer of library involvement in scholarship production.

\section{b. Law Library Consortia.}

55. See infra Section 4. 
To avoid the "reinventing the wheel" problem, law libraries can choose to collaborate within and across institutions to develop more costeffective scholarly publishing infrastructure. They could thereby further reduce the risk of rent-seeking from profit-driven organizations.

The pre-publication process is well-established and standardized among journals. Law journal editors rely heavily on products and services provided by for-profit vendors for those tasks. Submissions are collected and managed through services like Expresso and Scholastica. Librarian support is minimal at this stage. Editing is mostly handled in wordprocessing programs and cloud storage services. Workflows are generally inherited from past editing teams or developed ad hoc. Librarians offer most of their services at this juncture, and we can do more in terms of cloud storage services.

Once journal articles are published, dissemination is again largely provided by vendors. Legal information database vendors (Westlaw, Lexis, Hein, EBSCO, et al.) collect and index the articles. But, it does not need to remain as such. Many law schools subscribe to Elsevier's Digital Commons repository service for hosting and indexing for search engines. Before and after formal publication in a journal, articles are distributed via SSRN, SelectedWorks, ResearchGate, and Academia.edu. These are wholly owned and operated by for-profit organizations: SSRN and SelectedWorks are now part of Elsevier, and ResearchGate and Academia.com are also for-profit. ${ }^{56}$ Only repositories running on open source platforms and institution-owned computers, such as LawArXiv ${ }^{57}$ or DSpace, ${ }^{58}$ because they are built in-house, are fully controlled by the organizations most responsible with producing and sharing their own legal scholarship. Even if law schools choose to rely on for-profit vendors, the library is the unit best positioned to wrangle the variety of systems and tools. For example, SSRN has announced plans to integrate its citation metrics with CrossRef's citation network, ${ }^{59}$ and HeinOnline

56. See Rebecca Stuhr \& Sarah Wipperman, Sharing your Scholarship Through Social Media, slide 5, https://repository.upenn.edu/cgi/viewcontent.cgi?article=1012\&context=p enn_oa_events.

57. About, LAwARXIV, http://lawarxiv.info/about (last visited Sept. 29, 2020).

58. About, DURASPACE, https://duraspace.org/dspace/about/ (last visited Sept. 29, 2020).

59. See Trish Wilgar, SSRN launches improved Citations and References Service, SSRNBLOG (June 19, 2019), https://ssrnblog.com/2019/06/13/ssrns-new-citations/. 
and other vendors are preparing to integrate the ORCID (Open Research Contributor ID) system to improve author name disambiguation. ${ }^{60}$

While law schools are unusual in sponsoring and publishing most journals, in many other respects they have outsourced the actual publishing functions, paying with cash, data, and some control over the legal scholarship its faculty and students work so hard to create. We need to remember that we are already engaged in most aspects of the scholarship pre-publishing and dissemination. Perhaps what we need is to accept the status quo and build on it.

\section{CONCLUSION AND SUGGESTIONS}

We have argued that the increasing role of scholarly impact in determining a school's status will provide a new opportunity for libraries to assume a critical institutional role behind its traditional support of scholarship and teaching. In practice, this increased role can evolve in a multitude of ways. Based on the data used here, a strong argument can be made in favor of each library taking charge of both their faculty scholarly impact and publication of its school's journals. Based on the success story of Perma.cc, ${ }^{61}$ a good argument can be made in favor of creating a consortium supporting both these endeavors. Either way, our thesis is that libraries cannot confine themselves to the roles they played in the predigital era.

Law faculties create scholarship, and law students decide how much of that scholarship is published in student-edited journals. Academic law libraries are best situated to publish those journals on the digital platforms that librarians curate. Libraries have evolved from hubs of information into nuclei of scholarship support through creative use of technology. Law schools need us to streamline this process. Universities need us to start the long-due process of rethinking the libraries' role in the journal publishing enterprise.

60. See HeinOnline integrates with ORCID, LYRASIS (Jan. 27, 2020), https://lyrasisnow.org/heinonline-integrates-with-orcid/.

61. See Jonathan Zittrain, Kendra Albert \& Lawrence Lessig, Perma: Scoping and Addressing the Problem of Link and Reference Rot in Legal Citations, 127 HARV. L. REV. F. 176 (2014). 
Libraries tend to look at budgets as fifty percent personnel and fifty percent acquisitions. ${ }^{62}$ In times of recession they tend to go for layoffs rather than diminish their acquisition budgets because only the latter moves a library toward the top of a rankings list, or toward its bottom. ${ }^{63}$

But this is a fabricated reality. In our digital era, acquisitions are not what they used to be. Today, libraries acquire mostly journal articles and the same article comes from multiple aggregators. Furthermore, libraries have no way of ensuring that out of ten digital copies they will still have access to one when an aggregator goes belly up, because what libraries acquire is not a digital copy, but leased access points to evanescing digital content. ${ }^{64}$

Budgetary constraints are thus another reason for libraries to leave behind their passive collection role, to disavow their tenor as civil and docile partners of various vendors, and engage in a more active role in the scholarship production enterprise for the benefit of their scholarly constituency-locally, nationally, and globally. It is time for libraries to assume agency and act as partners in the process of scholarly production.

Finally, given the increased urgency of making available digital products that has been sparked by the new world COVID-19 has brought upon us, libraries need to rethink their institutional roles. ${ }^{65}$ Remaining within parameters dictated by the strictures of earlier information formats, and failing to envision expanded roles for themselves in the creation, communication, and preservation of scholarly information while

62. See AmericAn Library AsSOCIATION, Library Operating EXPENDITURES: A SELECTED ANNOTATED BIBLIOGRAPHY, http://www.ala.org/tools/libfactsheets/alalibraryfactsheet04 ("During fiscal year 2012, academic libraries spent about $\$ 3.4$ billion on salaries and wages, representing 49 percent of total library expenditures.") (emphasis added).

63. E.g., Lisa Peet, Academic Library Workers See Furloughs, Reduced Hours as Schools Anticipate Budget Cuts, LiBR. J. (July 13, 2020), https://www.libraryjournal.com/ ?detailStory=academic-library-workers-see-furloughs-reduced-hours-as-schools-anticipatebudget-cuts-covid-19.

64. Dana Neacsu, DRM Redux, in Digital Rights Management: The Librarian's GuidE_173 (Catherine A. Lemmer \& Carla P. Wale eds., 2016).

65. See Dana Neacsu, The Publishing Silver Lining Of COVID-19: New Opportunities for Institutional and Professional Relevance, AALL SPECTRUM/New VOICE (June 2020), https://www.aallnet.org/wp-content/uploads/2020/06/New-Voices-_-June-2020-DanaNeacsu.pdf. 
allowing others to take up the new responsibilities in reporting the impact of that scholarship, will only amount to a wasted opportunity. ${ }^{66}$

66. For mixed results of taken and wasted opportunities, see, for example, Dana Neacsu \& Sarah Witte, COVID-19 Silver Lining of Library Research Support for Students and Faculty Colum. U. Libr,=. Res. Presentation Series (May 12, 2020), https://doi.org/10.7916/d8keh9-9011. 


\title{
APPENDIX 1: ACADEMIC LAW LIBRARIES- SCHOLARSHIP PUBLICATION SURVEY
}

\author{
DANA NEACSU, BENJAMIN J. KEELE \& JAMES M. DONOVAN
}

Recent developments push forward the need to make faculty scholarship available to readers in hopes of increasing its impact. Although libraries have long played a critical role in the collection and preservation of faculty scholarship, the new environment can impose additional responsibilities to make the writings even more visible.

This survey asks a few brief questions to help learn how libraries are responding to these new pressures, and what practices they have adopted to increase visibility and perhaps impact. The goal is to identify helpful trends. Respondents are encouraged to share their thoughts on how they have reacted to these demands, and the direction in which they think libraries should move in the future. Kindly reply by May 31st, 2019. For any questions, please email Dana, edn13@ columbia.edu.

1. Does your law school library support the publication of your law school's student-edited journals in the following ways? Select all that apply, beyond the regular source gathering, reference-related services?

Formal training to large groups and/or to individual students

Assistance gathering sources for citation verification and/or formatting citations

Assistance evaluating article submissions

Adding journal content to research platforms (such as Westlaw, Lexis, HeinOnline, JSTOR)

Adding journal content to institutional platforms (such as institutional repositories and school websites)

Administering technology services (such as Perma, Scholastica, etc.)

Advising on copyright matters

Other (please specify)

2. Does your university library provide any of the services listed in Q1 that your law library does not? 
Yes

No

3. If your answer to Q2 was yes, please indicate the service.

4. Does your library electronically archive (actively collect and retain indefinitely) the scholarship published by the law school student-edited journals?

Yes

No

5. If your answer to Q4 is yes, please indicate (1) the platform used; and (2) the time-frame covered (starting with the first issue, etc.).

6. If your answer to Q4 is yes, is each archived article accessible through your library catalog? Is its full content freely available to nonaffiliates? Is the material locatable through search engines (e.g, Google, Bing, Duckduckgo, Baidu)? Does your library do anything to promote these materials in search engine results list (i.e., search engine optimization - SEO)? Check all that apply.

Yes, the archived article is accessible through the library catalog

No, the archived article is not accessible through the library catalog

Yes, its full content is freely available to non-affiliates

No, its full content is not freely available to non-affiliates

Yes, the archived material is locatable through search engines (e.g, Google, Bing, Duckduckgo, Baidu)

No, the archived material is not locatable through search engines (e.g, Google, Bing, Duckduckgo, Baidu)

Yes, the library does promote the archived material in search engine results list (i.e., search engine optimization - SEO)

No, the library does not promote the archived material in search engine results list (i.e., search engine optimization - SEO)

Other (please specify)

7. Does your library archive content published in law journal online supplements, conference presentations, and faculty blog posts?

Yes, the library archives content published in law journal online 
supplements

No, the library does not archive content published in law journal online supplements

Yes, the library archives faculty conference presentations

No, the library does not archive faculty conference presentations

Yes, the library archives faculty blog posts

No, the library does not archive faculty blog posts

Other

Other (please specify)

8. Please add any comments or suggestions you might think useful. 


\section{APPENDIX 2: ACADEMIC LAW LIBRARIES SCHOLARSHIP PUBLICATION SURVEY: RESPONSES}

Q1 Does your law school library support the publication of your law school's student-edited journals in the following ways? Select all that apply, beyond the regular source gathering, reference-related services?

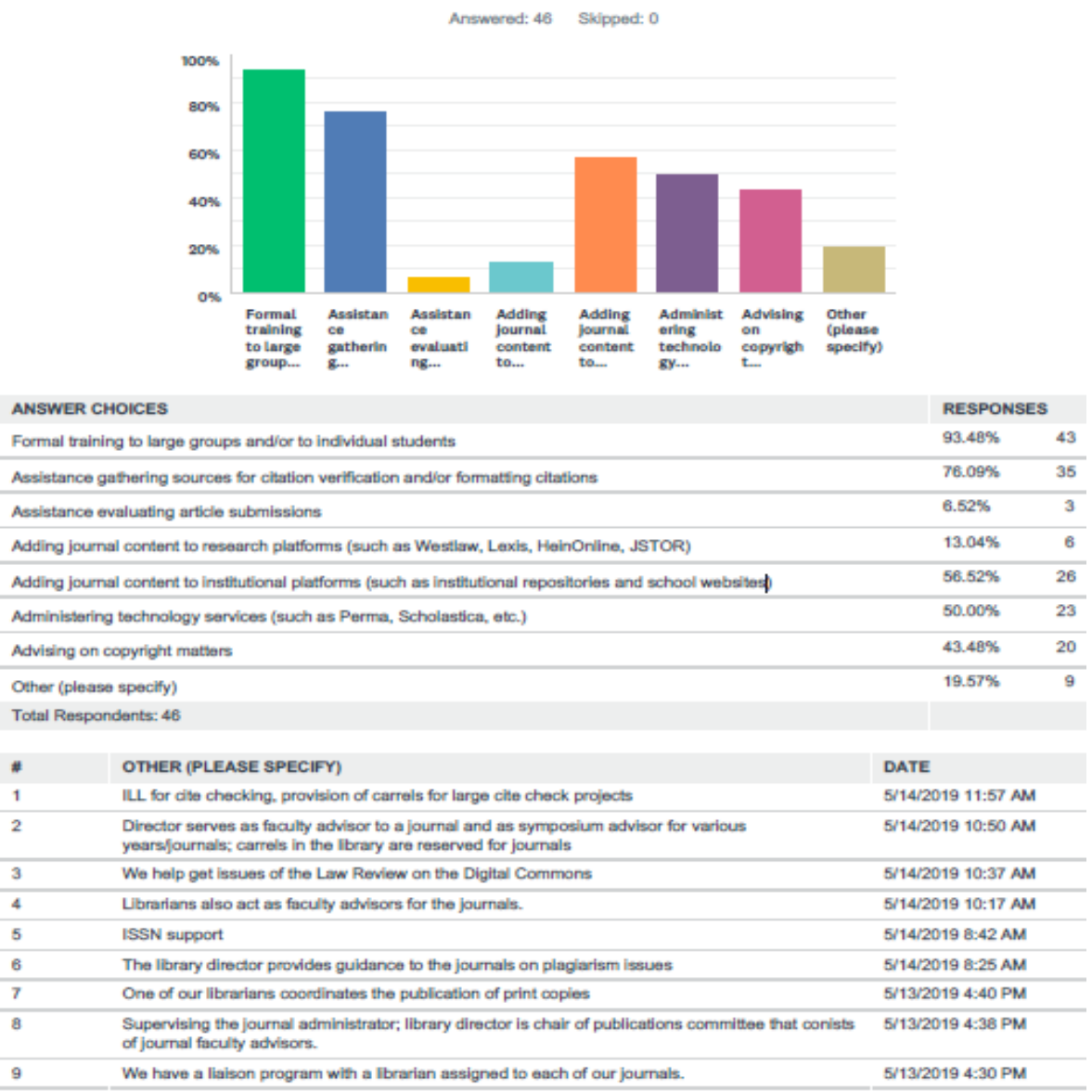


Q4 Does your library electronically archive (actively collect and retain indefinitely) the scholarship published by the law school student-edited journals?

Answered: 46 Skipped: 0

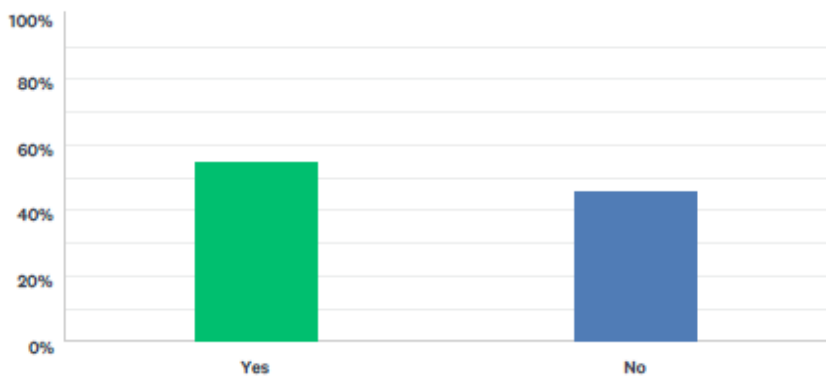

Yes

RESPONSES

\begin{tabular}{|c|c|}
\hline ANSWER CHOICES & RESPONSES \\
\hline Yes & $54.35 \%$ \\
\hline No & $45.65 \%$ \\
\hline TOTAL & \\
\hline
\end{tabular}


Q6 If your answer to Q4 is yes, is each archived article accessible through your library catalog? Is its full content freely available to nonaffiliates? Is the material locatable through search engines (e.g, Google, Bing, Duckduckgo, Baidu)? Does your library do anything to promote these materials in search engine results list (i.e., search engine optimization - SEO)? Check all that apply.

Answered: 27 Skipped: 19

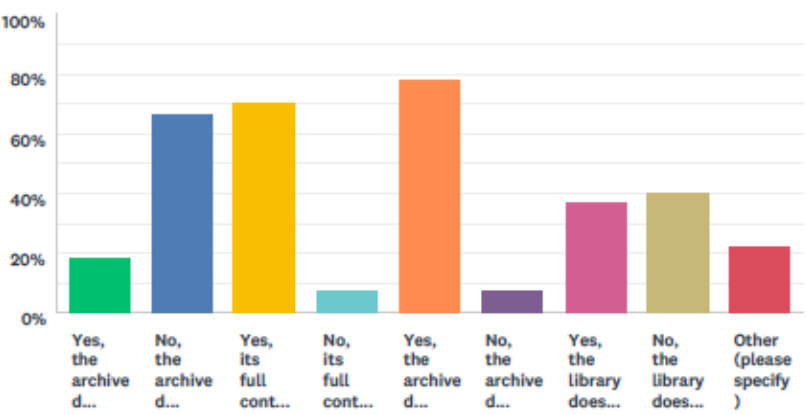

\begin{tabular}{|c|c|c|c|c|}
\hline \multicolumn{3}{|c|}{ ANSWER CHOICES } & \multicolumn{2}{|c|}{ RESPONSES } \\
\hline \multicolumn{3}{|c|}{ Yes, the archived article is accessible through the library catalog } & $18.52 \%$ & 5 \\
\hline \multicolumn{3}{|c|}{ No, the archived article is not accessible through the library catalog } & $66.67 \%$ & 18 \\
\hline \multicolumn{3}{|c|}{ Yes, its full content is freely available to non-affiliates } & $70.37 \%$ & 19 \\
\hline \multicolumn{3}{|c|}{ No, its full content is not freely available to non-affiliates } & $7.41 \%$ & 2 \\
\hline \multicolumn{3}{|c|}{ Yes, the archived material is locatable through search engines (e.g. Google, Bing, Duckduckgo, Baidu) } & $77.78 \%$ & 21 \\
\hline \multicolumn{3}{|c|}{ No, the archived material is not locatable through search engines (e.g. Google, Bing, Duckduckgo, Baidu) } & $7.41 \%$ & 2 \\
\hline \multicolumn{3}{|c|}{ Yes, the library does promote the archived material in search engine results list (i.e., search engine optimization - SEO) } & $37.04 \%$ & 10 \\
\hline \multicolumn{3}{|c|}{ No, the library does not promote the archived material in search engine results list (i.e., search engine optimization - SEO) } & $40.74 \%$ & 11 \\
\hline \multicolumn{3}{|c|}{ Other (please specify) } & $22.22 \%$ & 6 \\
\hline \multicolumn{3}{|c|}{ Total Respondents: 27} & & \\
\hline$\#$ & OTHER (PLEASE SPECIFY) & \multicolumn{3}{|l|}{ DATE } \\
\hline 1 & The IR vendor performs SEO & \multicolumn{3}{|c|}{ 5/15/2019 9:08 AM } \\
\hline 2 & $\begin{array}{l}\text { Some collections are available via the catalog and some are not. Digital Commons has excellent } \\
\text { SEO, so I'm not sure how the library would have a role there. }\end{array}$ & \multicolumn{3}{|c|}{ 5/14/2019 6:49 PM } \\
\hline 3 & $\begin{array}{l}\text { We have corrected article metadata and retrospectively provided individual article discovery from } \\
\text { both Hein Online and Digital Commons }\end{array}$ & \multicolumn{3}{|c|}{ 5/14/2019 10:50 AM } \\
\hline 4 & promotion through social and professional media platforms & \multicolumn{3}{|c|}{ 5/14/2019 8:42 AM } \\
\hline 5 & We don't use SEO, but Digital Commons does. & \multicolumn{3}{|c|}{ 5/13/2019 4:38 PM } \\
\hline 6 & $\mathrm{n} / \mathrm{a}$ & \multicolumn{3}{|c|}{$5 / 13 / 2019$ 4:37 PM } \\
\hline
\end{tabular}




\section{Section 4 - Staffing}

Please estimate the staffing level for your repository in hours/week.

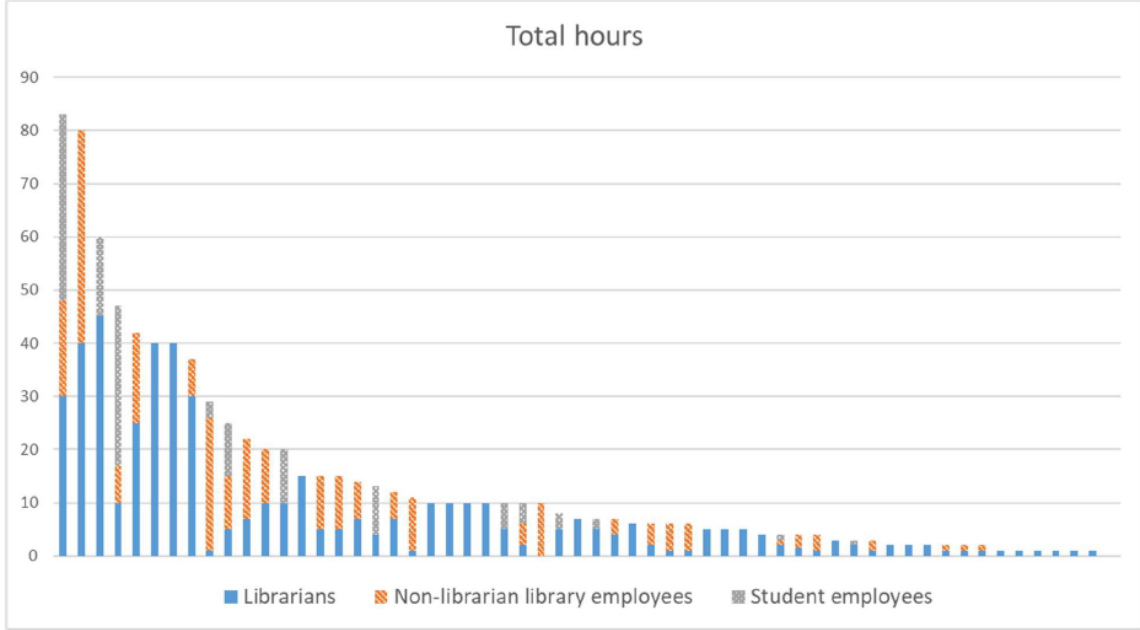




\section{APPENDIX 3: AALL LAW REPOSITORIES CAUCUS EDUCATION COMMITTEE SURVEY: EXCERPT DATA}

The purpose of this survey was to gain and share information about the operations and practices of law repositories.

The survey was open from April 16 to May 22, 2019 and received 79 total responses from 71 different law libraries.

Duplicate responses from the same library were removed from the data set. For each question on the survey,

percentages and other calculations reflect only the responses to that particular question, ignoring respondents who skipped the question.

AALL Law Repositories Caucus Education Committee, 2018-19 Erik Beck, California State University, Sacramento Anna Blaine, University of Idaho College of Law Pamela C. Brannon, Georgia State University College of Law Mary Godfrey-Rickards, CUNY School of Law Benjamin Keele, Indiana University Robert H. McKinney School of Law Cheryl Nyberg, University of Washington School of Law Michael Roffer, New York Law School Nick Szydlowski, Boston College Law School, Chair 


\section{Section 3 - Journals}

Q3.2 - When do you add new journal issues to your repository? (If you support journals that follow different practices, please select all that apply)

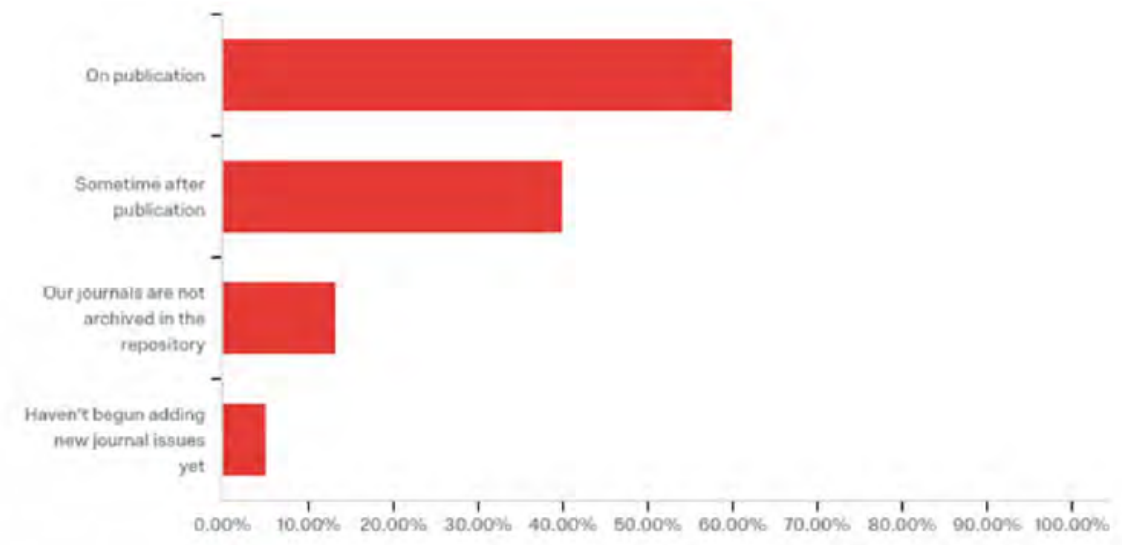

\begin{tabular}{l|r|r|r}
\hline$\#$ & Answer & $\%$ & Count \\
\hline 1 & On publication & $60.00 \%$ & 36 \\
\hline 2 & Sometime after publication & $40.00 \%$ & 24 \\
\hline 3 & Our journals are not archived in the repository & $13.33 \%$ & 8 \\
\hline 4 & Haven't begun adding new journal issues yet & $5.00 \%$ & 3 \\
\hline & Total & $100 \%$ & 60 \\
\hline
\end{tabular}


Q3.3 - Do your journals provide free access to their content through their own websites? (If you support journals that follow different practices, please select all that apply)

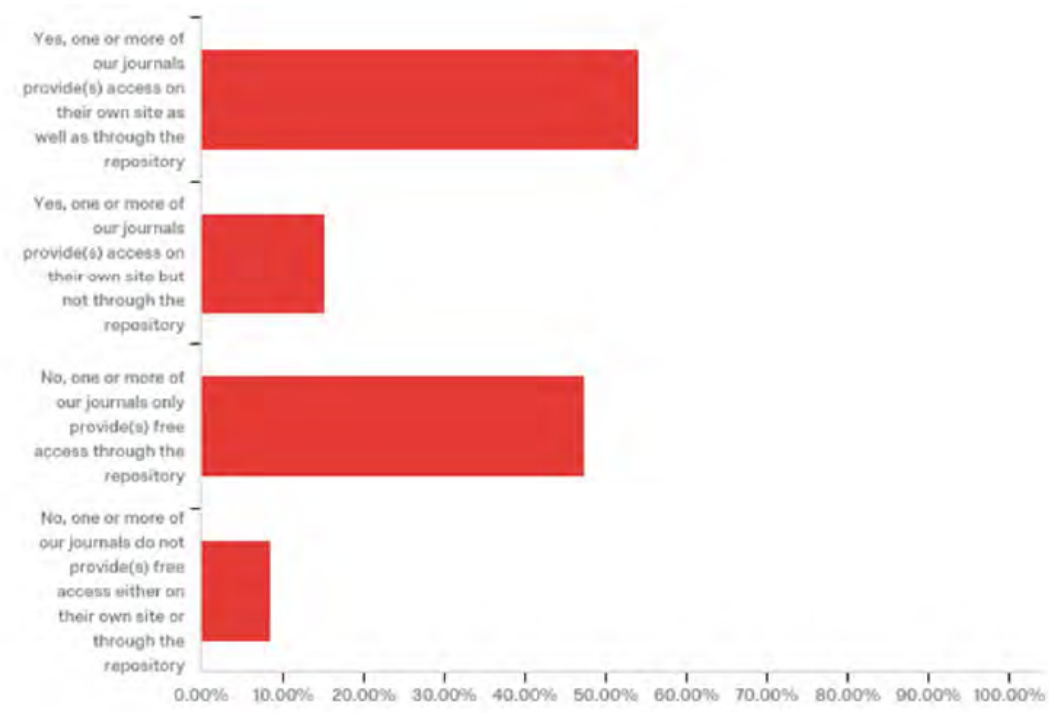

\begin{tabular}{|c|c|c|c|}
\hline \# & Answer & $\%$ & Count \\
\hline 1 & $\begin{array}{r}\text { Yes, one or more of our journals provide(s) access on their own site as well as through the } \\
\text { repository }\end{array}$ & $54.24 \%$ & 32 \\
\hline 3 & No, one or more of our journals only provide(s) free access through the repository & $47.46 \%$ & 28 \\
\hline 2 & $\begin{array}{r}\text { Yes, one or more of our journals provide(s) access on their own site but not through the } \\
\text { repository }\end{array}$ & $15.25 \%$ & 9 \\
\hline \multirow[t]{2}{*}{4} & $\begin{array}{r}\text { No, one or more of our journals do not provide(s) free access either on their own site or } \\
\text { through the repository }\end{array}$ & $8.47 \%$ & 5 \\
\hline & Total & $100 \%$ & 59 \\
\hline
\end{tabular}


Q3.4 - How are new journal issues added to your repository? (select all that apply)

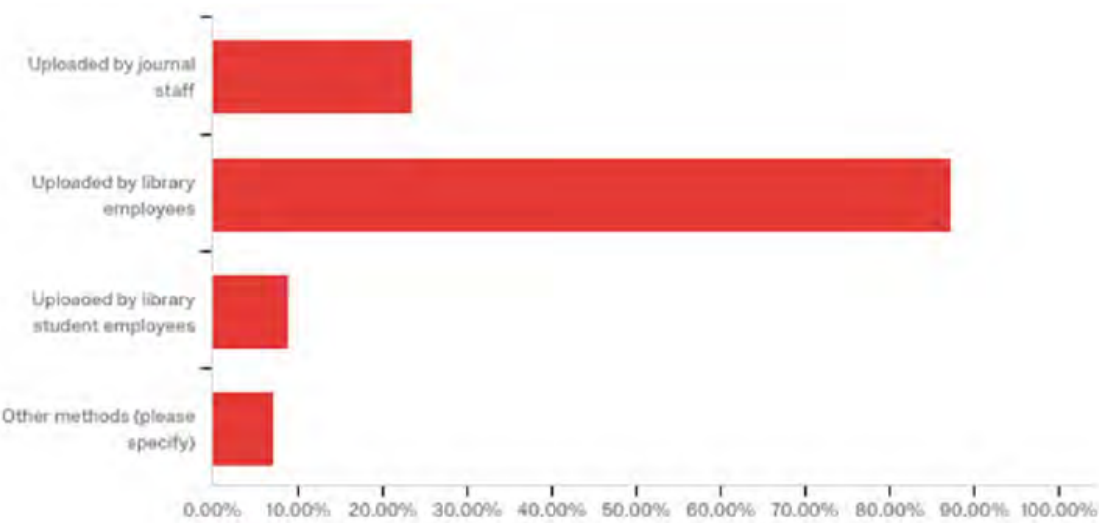

\begin{tabular}{l|r|r|r}
\hline$\#$ & Answer & $\%$ & Count \\
\hline 2 & Uploaded by library employees & $87.27 \%$ & 48 \\
\hline 1 & Uploaded by journal staff & $23.64 \%$ & 13 \\
\hline 3 & Uploaded by library student employees & $9.09 \%$ & 5 \\
\hline 4 & Other methods (please specify) & $7.27 \%$ & 4 \\
\hline & Total & $100 \%$ & 55
\end{tabular}


Q4.6 - What department(s) within your library contribute staff time to your repository?

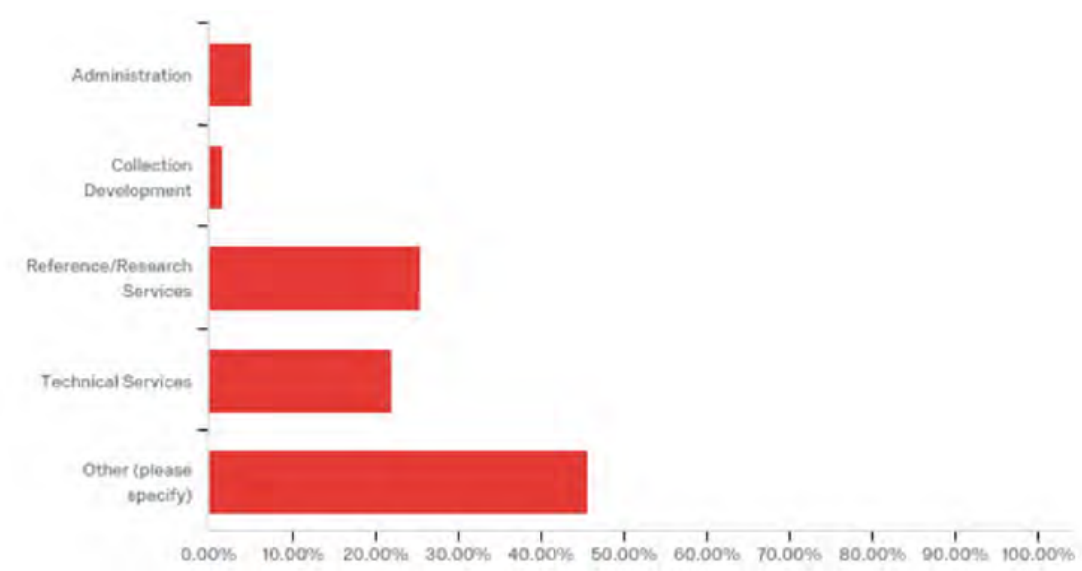

\begin{tabular}{|c|c|c|c|}
\hline$\#$ & Answer & $\%$ & Count \\
\hline 5 & Other (please specify) & $45.76 \%$ & 27 \\
\hline 3 & Reference/Research Services & $25.42 \%$ & 15 \\
\hline 4 & Technical Services & $22.03 \%$ & 13 \\
\hline 1 & Administration & $5.08 \%$ & 3 \\
\hline \multirow[t]{2}{*}{2} & Collection Development & $1.69 \%$ & 1 \\
\hline & Total & $100 \%$ & 59 \\
\hline
\end{tabular}




\section{APPENDIX 4: COMPARATIVE CITATION COUNTS FOR EIGHT CRIMINAL LAW SCHOLARS}

\begin{tabular}{|c|c|c|c|c|c|c|c|c|}
\hline Author & $\begin{array}{l}\text { Scholarship } \\
\text { Citation: }\end{array}$ & $\begin{array}{l}\text { Washington } \\
\text { \& Lee } 2018 \\
\text { Law Journal } \\
\text { Rankings } \\
\text { Combined } \\
\text { Score }\end{array}$ & $\begin{array}{l}\text { Hein } \\
\text { Citation } \\
\text { Counts }\end{array}$ & $\begin{array}{l}\text { KeyCite } \\
\text { Counts }\end{array}$ & $\begin{array}{l}\text { Shepards } \\
\text { Counts }\end{array}$ & $\begin{array}{l}\text { SSRN } \\
\text { Down } \\
\text { loads }\end{array}$ & $\begin{array}{l}\text { SSRN } \\
\text { Views }\end{array}$ & $\begin{array}{l}\text { Academic } \\
\text { Commons } \\
\text { downloads }\end{array}$ \\
\hline \multirow[t]{11}{*}{ Scholar 1} & $\begin{array}{l}\text { Total Counts } \\
\text { for } 13 \text { scholarly } \\
\text { works (2010- } \\
\text { 19) (as of } \\
12 / 11 / 2019)\end{array}$ & & 218 & 253 & 235 & 1387 & 8296 & 9025 \\
\hline & $\begin{array}{l}\text { Harv. L. Rev. } \\
\text { Art. (2019) }\end{array}$ & 93.9 & 2 & 1 & 3 & 0 & 0 & 0 \\
\hline & $\begin{array}{l}\text { Tex. L. Rev. } \\
\text { Art. (2017) }\end{array}$ & 63.5 & 3 & 4 & 4 & 0 & 0 & 0 \\
\hline & $\begin{array}{l}2016 \text { Sup. Ct. } \\
\text { Rev. Art. (2016) }\end{array}$ & 60.1 & 4 & 4 & 4 & 0 & 0 & 0 \\
\hline & $\begin{array}{l}\text { Geo. L.J. Art. } \\
\text { (2016) }\end{array}$ & 61.0 & 3 & 3 & 3 & 0 & 0 & 191 \\
\hline & $\begin{array}{l}\text { U. Miami L. } \\
\text { Rev. Art. (2016) }\end{array}$ & 17.4 & 0 & 7 & 5 & 0 & 0 & 533 \\
\hline & $\begin{array}{l}\text { Ch. in a book, } \\
\text { (West } \\
\text { Publishing } \\
\text { 2016). }\end{array}$ & NR & 0 & 0 & 0 & 0 & 0 & 0 \\
\hline & $\begin{array}{l}\text { UCLA L. Rev. } \\
\text { Art. (2015) }\end{array}$ & 53.4 & 46 & 51 & 48 & 612 & 2627 & 4075 \\
\hline & $\begin{array}{l}\text { Calif. L. Rev. } \\
\text { Art. (2014) }\end{array}$ & 60.2 & $\begin{array}{l}23 \\
\text { (including } \\
1 \text { case) }\end{array}$ & 27 & 29 & 228 & 1702 & 577 \\
\hline & $\begin{array}{l}\text { Harv. J. of Legal } \\
\text { Studies Art. } \\
\text { (2012) }\end{array}$ & 19.7 & 0 & 7 & 0 & 108 & 938 & 873 \\
\hline & $\begin{array}{l}\text { Geo. L.J. Art. } \\
\text { (2012) }\end{array}$ & 61.0 & 60 & 68 & 72 & 155 & 679 & 1030 \\
\hline
\end{tabular}




\begin{tabular}{|c|c|c|c|c|c|c|c|c|}
\hline & $\begin{array}{l}\text { Legal } \\
\text { Workshop, } \\
2012\end{array}$ & NR & 0 & 0 & 0 & 45 & 414 & 168 \\
\hline & $\begin{array}{l}\text { Am. Crim. L. } \\
\text { Rev. Art. (2012) }\end{array}$ & 19.7 & $\begin{array}{l}61 \\
\text { (including } \\
1 \text { case) }\end{array}$ & 61 & 49 & 52 & 350 & 1044 \\
\hline & $\begin{array}{l}\text { Yale L. \& Pol'y } \\
\text { Rev. Art. (2010) }\end{array}$ & 11.8 & 16 & 20 & 18 & 187 & 1586 & 534 \\
\hline Scholar 2 & $\begin{array}{l}\text { Total Counts } \\
\text { for } 9 \text { scholarly } \\
\text { works (2007- } \\
2019) \text { (as of } \\
12 / 11 / 2019)\end{array}$ & & 23 & 36 & 26 & 188 & 894 & 216 \\
\hline & $\begin{array}{l}\text { Columbia Pub L } \\
\text { Res Paper \& U } \\
\text { Iowa L Studies } \\
\text { Res Paper }\end{array}$ & NR & 0 & 0 & 0 & 39 & 272 & 21 \\
\hline & $\begin{array}{l}\text { Yale LJ Art. } \\
(2019)\end{array}$ & 100 & 0 & 2 & 0 & 149 & 622 & 0 \\
\hline & $\begin{array}{l}\text { Tulsa L. Rev. } \\
\text { Art. (2017) }\end{array}$ & NR & 0 & 0 & 0 & 0 & 0 & 0 \\
\hline & $\begin{array}{l}\text { Yale L.J. Art. } \\
\text { (2016) }\end{array}$ & 100 & $\begin{array}{l}11 \\
\text { (including } \\
4 \text { cases) }\end{array}$ & 17 & 13 & 0 & 0 & 0 \\
\hline & $\begin{array}{l}\text { Law and Social } \\
\text { Inquiry Art. } \\
\text { (2013) }\end{array}$ & 10.5 & 3 & 5 & 5 & 0 & 0 & 0 \\
\hline & $\begin{array}{l}\text { Book HUP } \\
(2009)\end{array}$ & NR & 0 & 0 & 0 & 0 & 0 & 0 \\
\hline & $\begin{array}{l}\text { Law \& Hist. } \\
\text { Rev. Art. (2008) }\end{array}$ & NR & 0 & 0 & 0 & 0 & 0 & 195 \\
\hline & $\begin{array}{l}\text { T. Jefferson L. } \\
\text { Rev. Art. (2007) }\end{array}$ & NR & 2 & 2 & 2 & 0 & 0 & 0 \\
\hline & $\begin{array}{l}\text { Colum. J.L. \& } \\
\text { Soc. Probs. Art. } \\
(2007)\end{array}$ & 6.4 & 7 & 10 & 6 & 0 & 0 & 0 \\
\hline Scholar 3 & $\begin{array}{l}\text { Total Counts } \\
\text { for } 11 \text { scholarly } \\
\text { writings (2020- }\end{array}$ & & 196 & 266 & 208 & 3061 & 17617 & 2792 \\
\hline
\end{tabular}




\begin{tabular}{|c|c|c|c|c|c|c|c|}
\hline $\begin{array}{l}2006) \text { (as of } \\
12 / 12 / 2019)\end{array}$ & & & & & & & \\
\hline $\begin{array}{l}\text { Cal. L. Rev. Art. } \\
\text { (forthcoming } \\
2020 \text { ) }\end{array}$ & 60.2 & 0 & 0 & 0 & 0 & 0 & 0 \\
\hline $\begin{array}{l}\text { Columbia L. } \\
\text { Rev. Art. (2019) }\end{array}$ & 72.4 & 7 & 8 & 6 & 385 & 1883 & 0 \\
\hline $\begin{array}{l}\text { Michigan L Rev. } \\
\text { Art. (2017) }\end{array}$ & 51.0 & 28 & 44 & 35 & 480 & 2407 & 124 \\
\hline $\begin{array}{l}\text { Northwestern } \\
\text { U. L. Rev. Art. } \\
(2017)\end{array}$ & 36.7 & 7 & 17 & 16 & 194 & 879 & 71 \\
\hline $\begin{array}{l}\text { Cal. L. Rev. Art. } \\
\text { (2016) }\end{array}$ & 60.2 & $\begin{array}{l}51 \\
\text { (including } \\
1 \text { case) }\end{array}$ & $\begin{array}{l}68 \\
\text { (including } \\
1 \text { case \& } 5 \\
\text { applte ct } \\
\text { docs) }\end{array}$ & $\begin{array}{l}55 \\
\text { (including } \\
1 \text { case) }\end{array}$ & 682 & 4413 & 145 \\
\hline $\begin{array}{l}\text { Harv.L.Rev. } \\
\text { Art. (2014) }\end{array}$ & 93.9 & $\begin{array}{l}51 \\
\text { (including } \\
3 \text { cases) }\end{array}$ & $\begin{array}{l}60 \\
\text { (including } \\
3 \text { cases and } \\
6 \text { applte ct } \\
\text { docs) }\end{array}$ & $\begin{array}{l}54 \\
\text { (including } \\
3 \text { cases \& } \\
\text { ct docs) }\end{array}$ & 413 & 2263 & 833 \\
\hline $\begin{array}{l}\text { NYU Rev L \& } \\
\text { Soc'l Change } \\
\text { Art. (2010) }\end{array}$ & 8.9 & 9 & 8 & 7 & 339 & 2043 & 394 \\
\hline $\begin{array}{l}\text { Geo. J. Poverty } \\
\text { Law \& Pol'y } \\
\text { Art. (2006) }\end{array}$ & NR & $\begin{array}{l}22 \\
\text { (including } \\
1 \text { case) }\end{array}$ & $\begin{array}{l}22 \\
\text { (including } \\
1 \text { case, } 1 \\
\text { applte ct } \\
\text { doc \& } 1 \\
\text { criminal } \\
\text { text/treatis } \\
\text { e) }\end{array}$ & $\begin{array}{l}6 \\
\text { (including } \\
1 \text { case \& } 2 \\
\text { Mass st } \\
\text { statutes) }\end{array}$ & 293 & 2338 & 1066 \\
\hline $\begin{array}{l}\text { Geo. L.J. Art. } \\
(2016)\end{array}$ & 61.0 & $\begin{array}{l}21 \text { (includin } \\
\mathrm{g} 1 \text { case) }\end{array}$ & $\begin{array}{l}33 \\
\text { (including } \\
2 \text { cases, } 7 \\
\text { ct docs, } 1 \\
\text { criminal } \\
\text { text/treatis } \\
\text { e \& } 1 \\
\text { crim.l.bul) }\end{array}$ & $\begin{array}{l}22 \\
\text { (including } \\
2 \text { cases) }\end{array}$ & 275 & 1391 & 159 \\
\hline $\begin{array}{l}\text { Harv. Civ. } \\
\text { Rghts-Civ }\end{array}$ & 27.2 & 0 & 6 & 7 & 0 & 0 & 0 \\
\hline
\end{tabular}




\begin{tabular}{|c|c|c|c|c|c|c|c|c|}
\hline & $\begin{array}{l}\text { Liberties L.Rev. } \\
\text { Art. (2006) }\end{array}$ & & & & & & & \\
\hline \multirow[t]{8}{*}{ Scholar 4} & $\begin{array}{l}\text { Total Counts } \\
\text { for } 7 \text { scholarly } \\
\text { works (2007- } \\
2019) \text { (as of } \\
12 / 12 / 2019)\end{array}$ & & 106 & 111 & 104 & 1193 & 10071 & 0 \\
\hline & $\begin{array}{l}\text { Duke L.J. Art. } \\
(2019)\end{array}$ & 48.6 & 4 & 4 & 2 & 228 & 1397 & 0 \\
\hline & $\begin{array}{l}2018 \text { U. Ill. L. } \\
\text { Rev. Art. (2018) }\end{array}$ & 39.5 & 2 & 3 & 0 & 69 & 606 & 0 \\
\hline & $\begin{array}{l}\text { Fordham Urb. } \\
\text { L.J. Online Art. } \\
\text { (Aug. 2017) }\end{array}$ & NR & 0 & 0 & 0 & 49 & 315 & 0 \\
\hline & $\begin{array}{l}\text { Colum. L. Rev. } \\
\text { Art. (2016) }\end{array}$ & 72.4 & 21 & 21 & 21 & 325 & 2388 & 0 \\
\hline & $\begin{array}{l}\text { Iowa L. Rev. } \\
\text { Art. (2016) }\end{array}$ & 58.4 & 39 & 41 & 40 & 307 & 3581 & 0 \\
\hline & $\begin{array}{l}\text { Geo. L.J. Art. } \\
(2016)\end{array}$ & 61.0 & 31 & 32 & 32 & 188 & 1555 & 0 \\
\hline & $\begin{array}{l}\text { Harv. C.R.-C.L. } \\
\text { L. Rev. Art. } \\
(2007)\end{array}$ & 27.2 & 9 & 10 & 9 & 27 & 229 & 0 \\
\hline \multirow[t]{5}{*}{ Scholar 5} & $\begin{array}{l}\text { Total Counts } \\
\text { for } 24 \text { scholarly } \\
\text { works (1994- } \\
2019) \text { (as of } \\
12 / 12 / 2019)\end{array}$ & & $\begin{array}{l}877 \text { (\#25 } \\
\text { included) }\end{array}$ & 862 & 770 & 7603 & 63010 & 0 \\
\hline & $\begin{array}{l}\text { Yale L.J. Art. } \\
\text { (2019) }\end{array}$ & 100 & 1 & 1 & 0 & 65 & 251 & 0 \\
\hline & $\begin{array}{l}\text { book- Basic } \\
\text { Books (2018) }\end{array}$ & NR & 8 & 0 & 0 & 0 & 0 & 0 \\
\hline & $\begin{array}{l}\text { book, NYU } \\
\text { Press (2017) }\end{array}$ & NR & 40 & 0 & 0 & 0 & 0 & 0 \\
\hline & $\begin{array}{l}\text { Ohio St. J. } \\
\text { Crim. L. Art. } \\
(2017)\end{array}$ & 15.6 & 3 & 4 & 5 & 71 & 273 & 0 \\
\hline
\end{tabular}




\begin{tabular}{|c|c|c|c|c|c|c|c|}
\hline $\begin{array}{l}\text { Ch. in book ( } \\
\text { 2017), }\end{array}$ & NR & 0 & 0 & 0 & 275 & 1122 & 0 \\
\hline $\begin{array}{l}\text { Ch. in book, } \\
\text { Cambridge UP } \\
(2017)\end{array}$ & NR & 4 & 0 & 0 & 225 & 1224 & 0 \\
\hline $\begin{array}{l}\text { Ch. (Oxford } \\
\text { Handbooks } \\
\text { online) (2016) }\end{array}$ & NR & 1 & 0 & 0 & 0 & 0 & 0 \\
\hline $\begin{array}{l}\text { Annual Rev. of } \\
\text { Law and Soc. } \\
\text { Science Art. } \\
(2015)\end{array}$ & 9.1 & 0 & 14 & 0 & 275 & 1122 & 0 \\
\hline $\begin{array}{l}\text { Vand. L. Rev. } \\
\text { Art. (2015) }\end{array}$ & 56.9 & 77 & 86 & 85 & 662 & 4323 & 0 \\
\hline $\begin{array}{l}\text { Ohio St. J. } \\
\text { Crim. L. Art. } \\
(2015)\end{array}$ & 15.6 & 17 & 19 & 17 & 446 & 3373 & 0 \\
\hline $\begin{array}{l}\text { Fordham Urb. } \\
\text { L.J. Art. (2013) }\end{array}$ & 15.7 & 22 & 31 & 27 & 227 & 2114 & 0 \\
\hline $\begin{array}{l}\text { Wash. \& Lee L. } \\
\text { Rev. Art. (2013) }\end{array}$ & 37.8 & 33 & 34 & 33 & 232 & 2090 & 0 \\
\hline $\begin{array}{l}\text { S. Cal. L. Rev. } \\
\text { Art. (2012) }\end{array}$ & 44.8 & 168 & 187 & 170 & 1415 & 10,906 & 0 \\
\hline $\begin{array}{l}\text { book NYU } \\
\text { Press (2011) }\end{array}$ & NR & 82 & 0 & 0 & 0 & 652 & 0 \\
\hline $\begin{array}{l}\text { Cardozo L. Rev. } \\
\text { Art. (2008) }\end{array}$ & 35.0 & 22 & 23 & 20 & 362 & 3096 & 0 \\
\hline $\begin{array}{l}\text { Fordham L. } \\
\text { Rev. Art. (2006) }\end{array}$ & 60.5 & 102 & 106 & 104 & 390 & 4337 & 0 \\
\hline $\begin{array}{l}\text { Golden Gate U. } \\
\text { L. Rev. Art. } \\
(2006) \text {. }\end{array}$ & NR & $\begin{array}{l}45 \\
\text { (including } \\
3 \text { cases) }\end{array}$ & $\begin{array}{l}107 \\
\text { (including } \\
2 \text { cases \& } \\
41 \text { applt ct } \\
\text { docs) }\end{array}$ & $\begin{array}{l}66 \\
\text { (includiong } \\
2 \text { cases) }\end{array}$ & 1109 & 7651 & 0 \\
\hline $\begin{array}{l}\text { N.Y.U. L. Rev. } \\
\text { Art. (2005) }\end{array}$ & 54.9 & $\begin{array}{l}82 \\
\text { (including } \\
4 \text { cases) }\end{array}$ & $\begin{array}{l}93 \\
\text { (including } \\
4 \text { cases \& } 7 \\
\text { applt ct } \\
\text { docs) }\end{array}$ & $\begin{array}{l}90 \\
\text { (including } \\
4 \text { cases \& } 1 \\
\text { applt ct } \\
\text { doc) }\end{array}$ & 211 & 3652 & 0 \\
\hline
\end{tabular}




\begin{tabular}{|c|c|c|c|c|c|c|c|c|}
\hline & $\begin{array}{l}\text { Loyola-LA } \\
\text { Legal Studies } \\
\text { Paper ( 2005) }\end{array}$ & NR & 0 & 0 & 0 & 194 & 2329 & 0 \\
\hline & $\begin{array}{l}\text { U. Cin. L. Rev. } \\
\text { Art. (2004) }\end{array}$ & 12.6 & 83 & 112 & 94 & 1361 & 12378 & 0 \\
\hline & $\begin{array}{l}\text { Am. U. L. Rev. } \\
\text { Art. (1996) }\end{array}$ & 27.8 & 8 & 9 & 9 & 0 & 0 & 0 \\
\hline & $\begin{array}{l}\text { Stan. L. Rev. } \\
\text { Art. (1995) }\end{array}$ & 76.8 & 54 & 36 & 50 & 83 & 2117 & 0 \\
\hline & $\begin{array}{l}\text { J.L. \& Ed. Art. } \\
(1995)\end{array}$ & NR & 0 & 0 & 0 & 0 & 0 & 0 \\
\hline & $\begin{array}{l}\text { W. Educ. L. } \\
\text { Rep. Art. (1994) }\end{array}$ & NR & $\begin{array}{l}\# 25 \text { results } \\
\text { searching } \\
\text { Hein }\end{array}$ & 0 & 0 & 0 & 0 & 0 \\
\hline Scholar 6 & $\begin{array}{l}\text { Total Counts } \\
\text { for } 33 \text { scholarly } \\
\text { writings ( } 2005- \\
2020) \text { (as of } \\
12 / 13 / 19)\end{array}$ & & 592 & 609 & 547 & 4368 & 33399 & 5960 \\
\hline & $\begin{array}{l}\text { book, Univ. Cal. } \\
\text { U.Press (2020) }\end{array}$ & NR & 0 & 0 & 0 & 0 & 0 & 0 \\
\hline & $\begin{array}{l}\text { Crit. Analysis L. } \\
\text { Art. (2019) }\end{array}$ & NR & 0 & 0 & 0 & 94 & 1695 & 36 \\
\hline & $\begin{array}{l}\text { online Art. } \\
\text { (2019) }\end{array}$ & NR & 0 & 0 & 0 & 0 & 0 & 9 \\
\hline & $\begin{array}{l}\text { Book, Carolina } \\
\text { Ac. Press (2012) }\end{array}$ & NR & 0 & 0 & 0 & 0 & 0 & 0 \\
\hline & $\begin{array}{l}\text { Nw. U. L. Rev. } \\
\text { Art. (2018) }\end{array}$ & 36.7 & 4 & 4 & 4 & 43 & 355 & $\begin{array}{l}145 \\
\text { (Northwestern) } \\
+51 \text { (Colorado) }\end{array}$ \\
\hline & $\begin{array}{l}\text { Ch. (Oxford } \\
\text { Handbook } \\
\text { online) (2017) }\end{array}$ & NR & 0 & 0 & 0 & 16 & 227 & 0 \\
\hline & $\begin{array}{l}\text { Fla. L. Rev. Art. } \\
\text { (2016) }\end{array}$ & 42.7 & 9 & 12 & $\begin{array}{l}0 \text { (problem } \\
\text { with the } \\
\text { link) }\end{array}$ & 380 & 2421 & 9 \\
\hline
\end{tabular}




\begin{tabular}{|c|c|c|c|c|c|c|c|}
\hline $\begin{array}{l}\text { Cardozo L. Rev. } \\
\text { Art. (2016). }\end{array}$ & 35.0 & $\begin{array}{l}14 \\
\text { (including } \\
1 \text { by ALI) }\end{array}$ & $\begin{array}{l}22 \\
\text { (including } \\
7 \text { trial \& } \\
\text { appelate ct } \\
\text { docs) }\end{array}$ & 14 & 237 & 984 & 1619 \\
\hline $\begin{array}{l}\text { U. Kan. L. Rev. } \\
\text { Art. (2016) }\end{array}$ & 10.1 & 10 & 9 & 10 & 421 & 2130 & 171 \\
\hline $\begin{array}{l}\text { Ohio St. J. } \\
\text { Crim. L. Art. } \\
\text { (2016) }\end{array}$ & 15.6 & 6 & 7 & 6 & 68 & 351 & 86 \\
\hline $\begin{array}{l}\text { U. Pac. L. Rev. } \\
\text { Art. (2016) }\end{array}$ & NR & 0 & 7 & 2 & 0 & 0 & 482 \\
\hline $\begin{array}{l}\text { AJIL Unbound } \\
\text { Art. } \\
(2015 / 2016)\end{array}$ & 23.3 & 2 & 2 & 0 & 0 & 0 & 80 \\
\hline $\begin{array}{l}\text { Cal. L. Rev. Art. } \\
\text { (2015) }\end{array}$ & 60.2 & $\begin{array}{l}13 \\
\text { (including } \\
2 \text { cases) }\end{array}$ & $\begin{array}{l}13 \\
\text { (including } \\
2 \text { cases) }\end{array}$ & $\begin{array}{l}12 \\
\text { (including } \\
2 \text { cases) }\end{array}$ & 88 & 504 & 0 \\
\hline $\begin{array}{l}\text { Fordham L. } \\
\text { Rev. Art. (2015) }\end{array}$ & 60.5 & 19 & 20 & 18 & 52 & 369 & 120 \\
\hline $\begin{array}{l}\text { U. Miami L. } \\
\text { Rev. Art. (2014) }\end{array}$ & 17.4 & 17 & 20 & 16 & 158 & 821 & 132 \\
\hline $\begin{array}{l}\text { U. Colo. L. Rev. } \\
\text { Art. (2014) }\end{array}$ & 20.9 & 12 & 12 & 16 & 107 & 781 & 0 \\
\hline $\begin{array}{l}\text { Houston L. Rev } \\
\text { Art. (2013) }\end{array}$ & 20.7 & 18 & 20 & 16 & 320 & 1575 & 1101 \\
\hline $\begin{array}{l}\text { Comp. L. Rev. } \\
\text { Art. (2012) }\end{array}$ & NR & 6 & 0 & 0 & 0 & 0 & 0 \\
\hline $\begin{array}{l}\text { J. Gender, Race } \\
\text { \& Just. Art. } \\
(2012)\end{array}$ & 6.5 & 19 & 21 & 11 & 0 & 0 & 882 \\
\hline $\begin{array}{l}\text { Alb. L. Rev. Art. } \\
(2012 / 13)\end{array}$ & 14.4 & 8 & 8 & 7 & 0 & 0 & 255 \\
\hline $\begin{array}{l}\text { Ga. St. U. L. } \\
\text { Rev. Art. (2011) }\end{array}$ & NR & 5 & 5 & 5 & 0 & 0 & 0 \\
\hline $\begin{array}{l}\text { Wm. \& Mary L. } \\
\text { Rev. Art. (2010) }\end{array}$ & 44.8 & 27 & 31 & 28 & 212 & 3969 & 218 \\
\hline
\end{tabular}




\begin{tabular}{|c|c|c|c|c|c|c|c|c|}
\hline & $\begin{array}{l}\text { Wash. L. Rev. } \\
\text { Art. (2009) }\end{array}$ & 36.5 & 106 & 103 & 98 & 691 & 4420 & 0 \\
\hline & $\begin{array}{l}\text { U.C. Davis L. } \\
\text { Rev. Art. (2008). }\end{array}$ & 41.7 & 29 & 31 & 27 & 78 & 624 & 0 \\
\hline & $\begin{array}{l}\text { F Int'l U. L. } \\
\text { Rev. Art. (2007) }\end{array}$ & NR & 1 & 0 & 0 & 0 & 0 & 0 \\
\hline & $\begin{array}{l}\text { Iowa L. Rev. Art. } \\
(2007)\end{array}$ & 58.4 & 117 & 119 & 113 & 649 & 4408 & 456 \\
\hline & $\begin{array}{l}\text { Ariz. St. L.J. Art. } \\
(2007)\end{array}$ & 17.6 & $\begin{array}{l}23 \\
\text { (including } \\
1 \text { case) }\end{array}$ & $\begin{array}{l}22 \\
\text { (including } \\
1 \text { case) }\end{array}$ & $\begin{array}{l}22 \\
\text { (including } \\
1 \text { case) }\end{array}$ & 166 & 1239 & 0 \\
\hline & $\begin{array}{l}\text { U. Kan. L. Rev. } \\
\text { Art. (2006). }\end{array}$ & 10.1 & 32 & 28 & 31 & 281 & 2095 & 0 \\
\hline & $\begin{array}{l}\text { Buff. L. Rev. } \\
\text { Art. (2004) }\end{array}$ & 13.2 & 23 & 26 & 21 & 59 & 1225 & 159 \\
\hline & $\begin{array}{l}\text { Temp. L. Rev. } \\
\text { Art. (2003) }\end{array}$ & 16.2 & 21 & 22 & 29 & 248 & 3206 & 0 \\
\hline & $\begin{array}{l}\text { Wm. \& Mary J. } \\
\text { Women \& L. } \\
\text { Art. (1997) }\end{array}$ & 8.7 & 31 & 25 & 22 & 0 & 0 & 0 \\
\hline & $\begin{array}{l}\text { Harv. Int'l L.J. } \\
\text { Art. (1997) }\end{array}$ & 17.1 & 6 & 6 & 4 & 0 & 0 & 0 \\
\hline & $\begin{array}{l}\text { Seton Hall L. } \\
\text { Rev. Art. (2005) }\end{array}$ & 14.1 & 14 & 14 & 15 & 0 & 0 & 0 \\
\hline Scholar 7 & $\begin{array}{l}\text { Total Counts } \\
\text { for } 7 \text { scholarly } \\
\text { works (2013- } \\
2019)(\text { as of } \\
12 / 17 / 19)\end{array}$ & & 55 & 118 & 72 & 2085 & 11234 & 0 \\
\hline & $\begin{array}{l}\text { Ch. in book } \\
(2019)\end{array}$ & NR & 0 & 0 & 0 & 0 & 0 & 0 \\
\hline & $\begin{array}{l}\text { Ohio St. J. } \\
\text { Crim. L. Art. } \\
(2018)\end{array}$ & 15.6 & 23 & 30 & 20 & 783 & 3624 & 0 \\
\hline & $\begin{array}{l}\text { Citizenship } \\
\text { Stud. Art. } \\
(2017)\end{array}$ & NR & 0 & 0 & 0 & 115 & 586 & 0 \\
\hline
\end{tabular}




\begin{tabular}{|c|c|c|c|c|c|c|c|c|}
\hline & $\begin{array}{l}\text { J.L. Educ. Art. } \\
(2015)\end{array}$ & 14.9 & 25 & 26 & 0 & 452 & 2428 & 0 \\
\hline & $\begin{array}{l}\text { UCLA L. Rev. } \\
\text { Art. (2015) }\end{array}$ & 53.4 & 5 & 23 & 22 & 295 & 2077 & 0 \\
\hline & $\begin{array}{l}\text { U.C. Irvine L. } \\
\text { Rev. Art. (2013) }\end{array}$ & NR & 2 & 39 & 30 & 309 & 1826 & 0 \\
\hline & $\begin{array}{l}\text { Ch. in book } \\
\text { (Routledge } \\
\text { 2013) }\end{array}$ & NR & 0 & 0 & 0 & 131 & 693 & 0 \\
\hline Scholar 8 & $\begin{array}{l}\text { Total Counts } \\
\text { for } 8 \text { scholarly } \\
\text { works (2007- } \\
\text { 19) (as of } \\
12 / 17 / 19)\end{array}$ & & 149 & 177 & 171 & 1007 & 9555 & 2186 \\
\hline & $\begin{array}{l}\text { U. Pa. L. Rev. } \\
\text { Art. } \\
\text { (forthcoming } \\
\text { 2019). }\end{array}$ & $\begin{array}{l}\text { (69.9: Not } \\
\text { included in } \\
\text { calculations } \\
\text { since } \\
\text { forthcoming at } \\
\text { time of data } \\
\text { collection) }\end{array}$ & 0 & 0 & 0 & 76 & 538 & 70 \\
\hline & $\begin{array}{l}\text { B.U. L. Rev. } \\
\text { Art. (2018) }\end{array}$ & 51.7 & 10 & 12 & 12 & 72 & 385 & 10 \\
\hline & $\begin{array}{l}\text { Duke L.J. Art. } \\
\text { (2018) }\end{array}$ & 48.6 & 12 & 15 & 16 & 92 & 557 & 649 \\
\hline & $\begin{array}{l}\text { Tex. L. Rev. } \\
\text { Art. (2017) }\end{array}$ & 63.5 & 1 & 1 & 2 & 25 & 260 & 261 \\
\hline & $\begin{array}{l}\text { Geo. L.J. Art. } \\
\text { (2016) }\end{array}$ & 61.0 & 26 & 33 & 28 & 233 & 2058 & 0 \\
\hline & $\begin{array}{l}\text { Stan. L. Rev. } \\
\text { Art. (2015) }\end{array}$ & 76.8 & 82 & 95 & 91 & 338 & 2810 & 1106 \\
\hline & $\begin{array}{l}\text { Geo. Immigr. L. } \\
\text { J. Art. (2010). }\end{array}$ & NR & 13 & 15 & 15 & 151 & 1846 & 0 \\
\hline & Yale L. J. (2007) & 100 & 5 & 6 & 7 & 20 & 1101 & 90 \\
\hline
\end{tabular}




\section{APPENDIX 5: CITATIONS FOR EIGHT CRIMINAL LAW SCHOLARS: INDIVIDUAL RESULTS}

Scholar 1: Total Citations of 13 Works Reported in Each Source

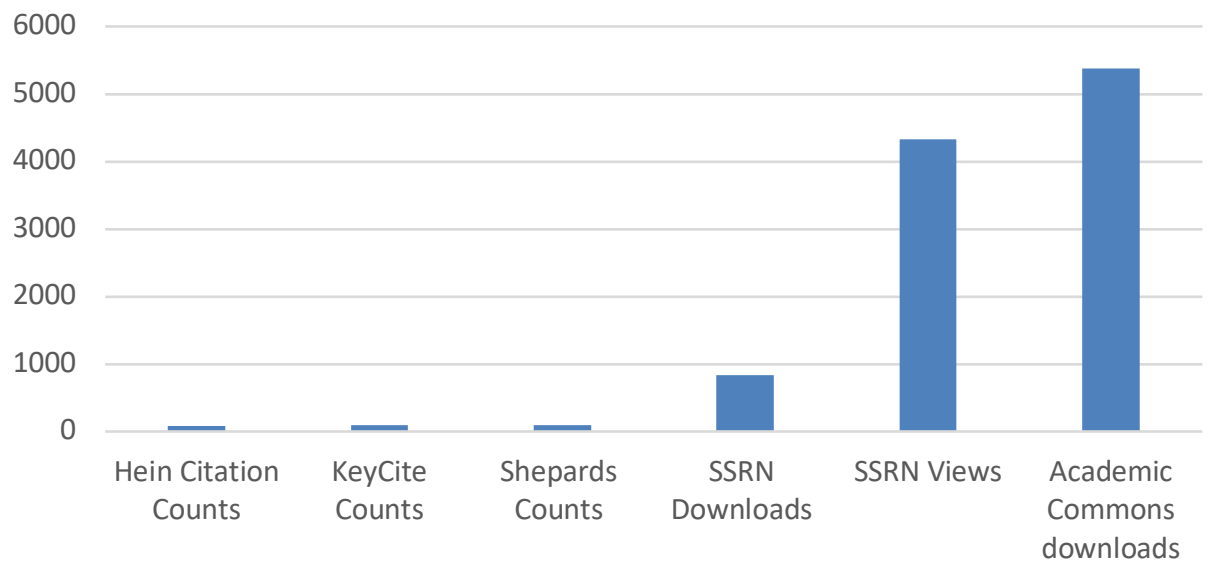

Scholar 1: Hein, KeyCite, Shepard's Comparison of Citations for 13 Works

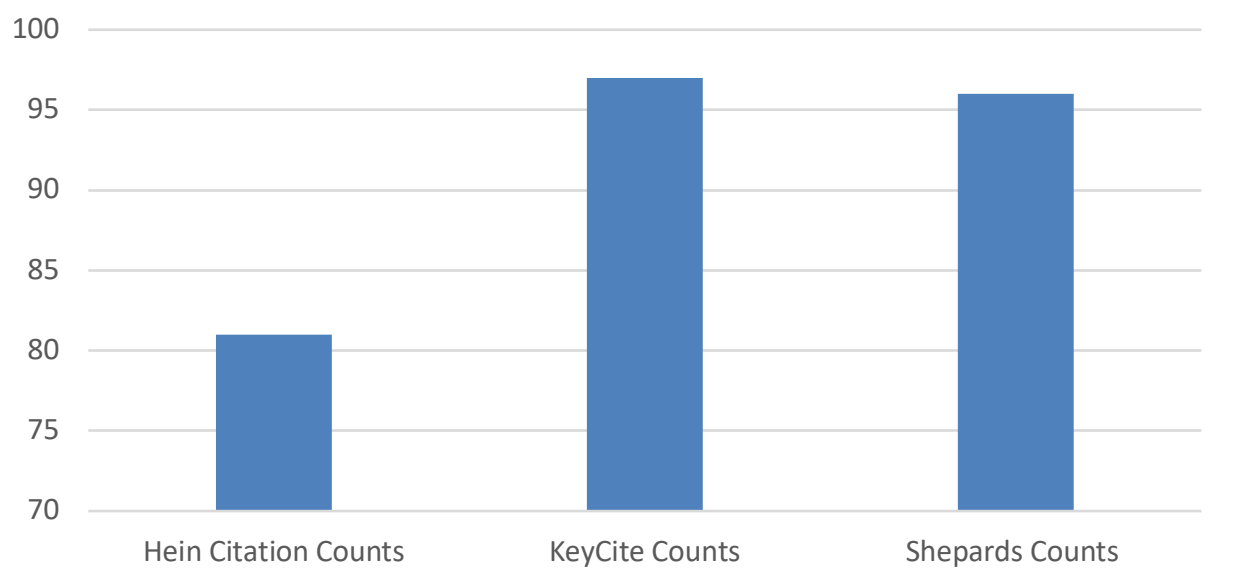




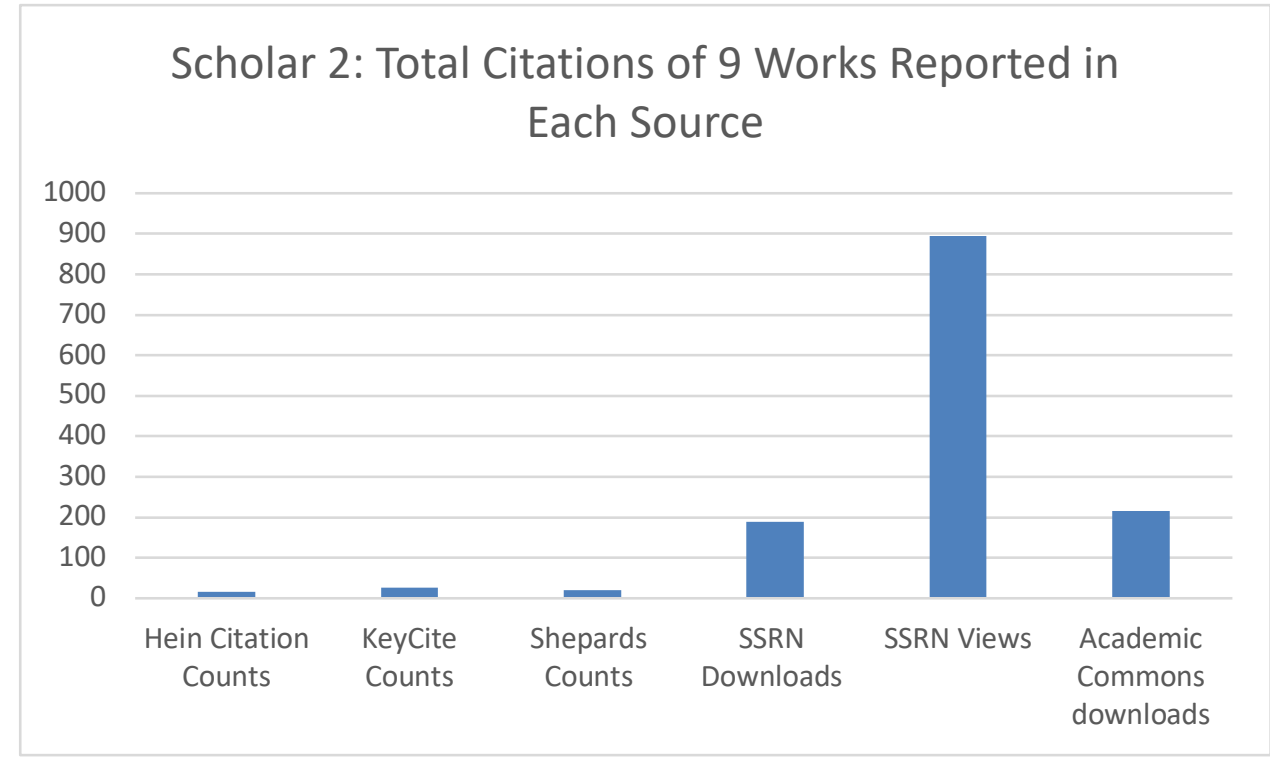

Scholar 2: Hein, KeyCite, Shepard's Comparison of Citations for 9 Works

30

25

20

15

10

5

0
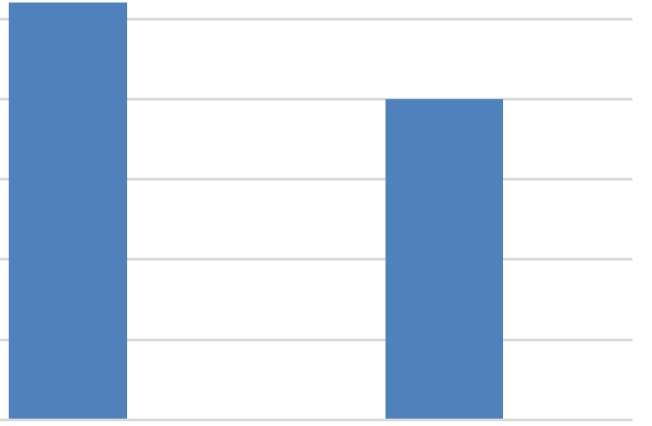

Hein Citation Counts

KeyCite Counts

Shepards Counts 
Scholar 3: Total Citations of 10 Works Reported in Each Source

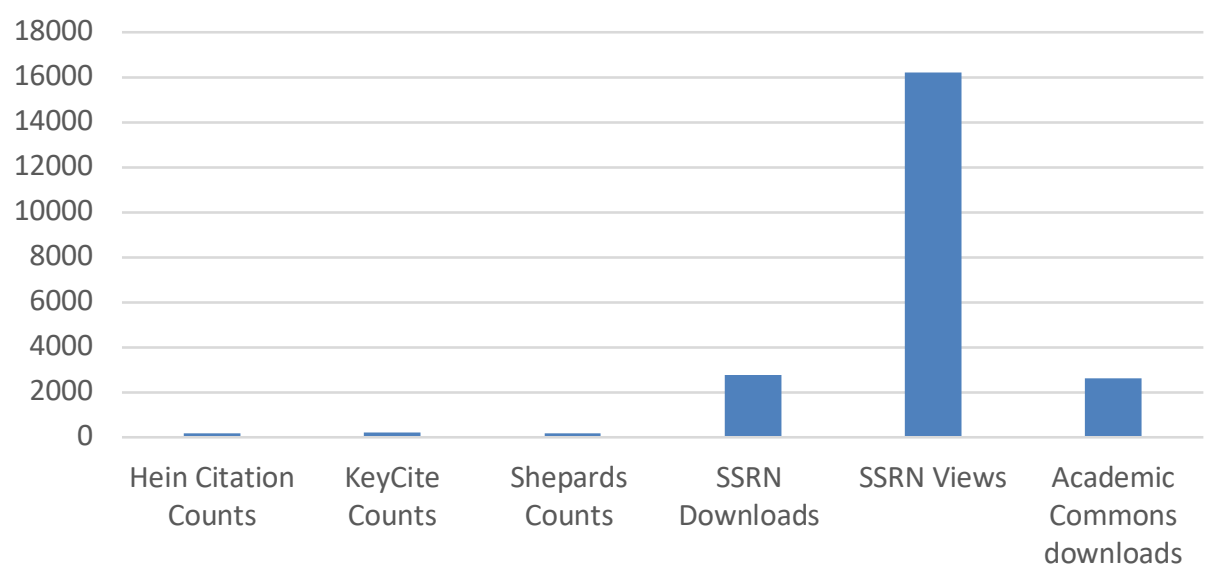

Scholar 3: Hein, KeyCite, Shepard's Comparison of Citations for 10 Works

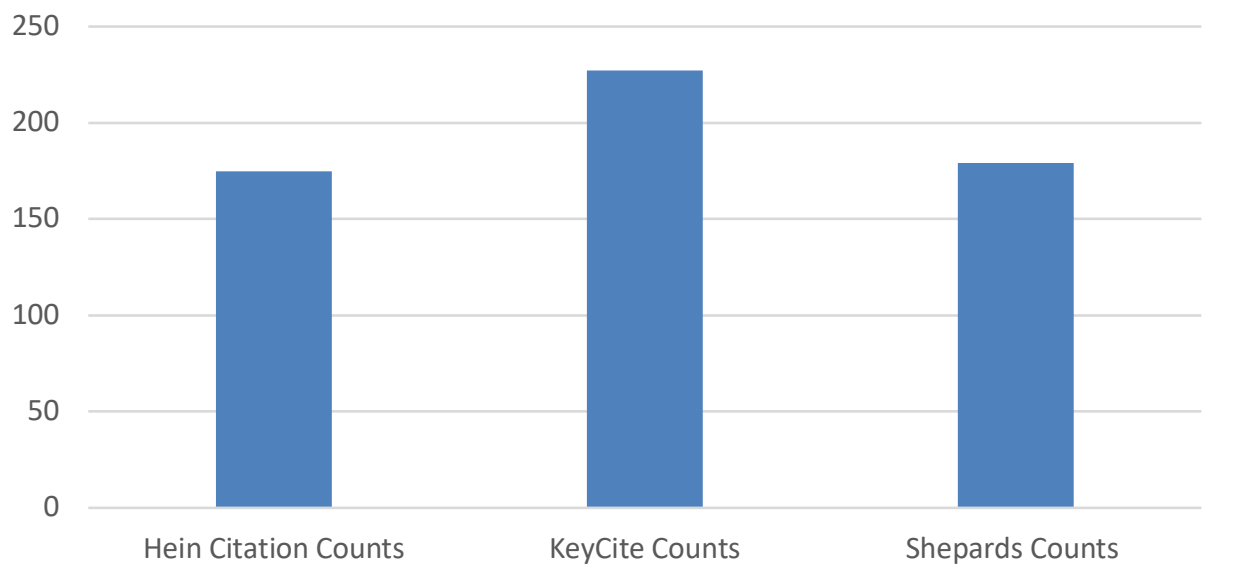


Scholar 4: Total Citations of 7 Works Reported in Each Source

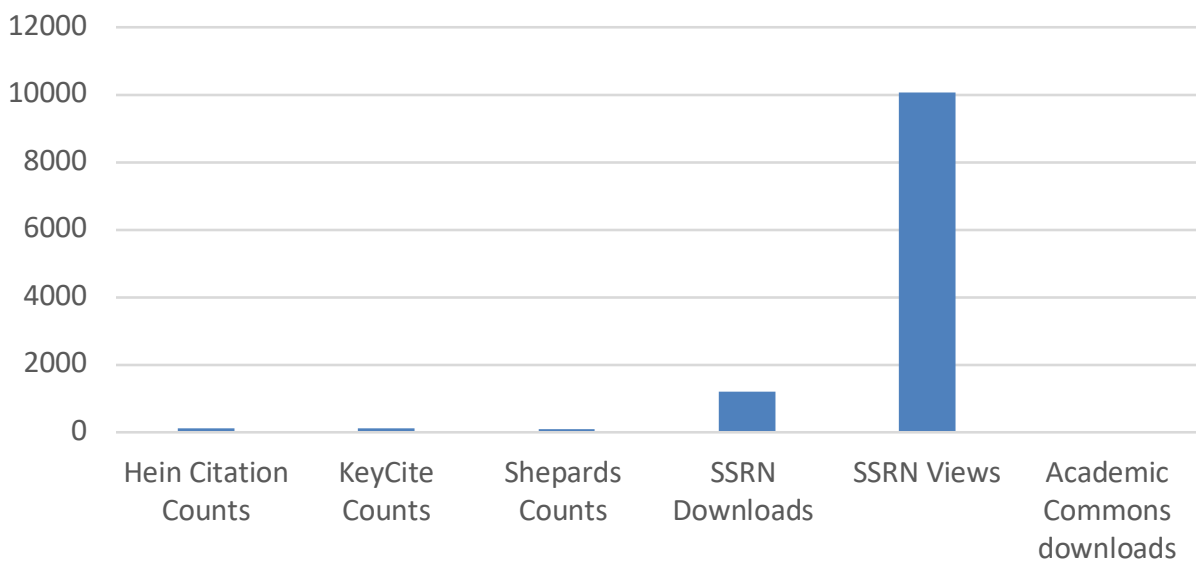

Scholar 4: Hein, KeyCite, Shepard's Comparison of Citations for 7 Works

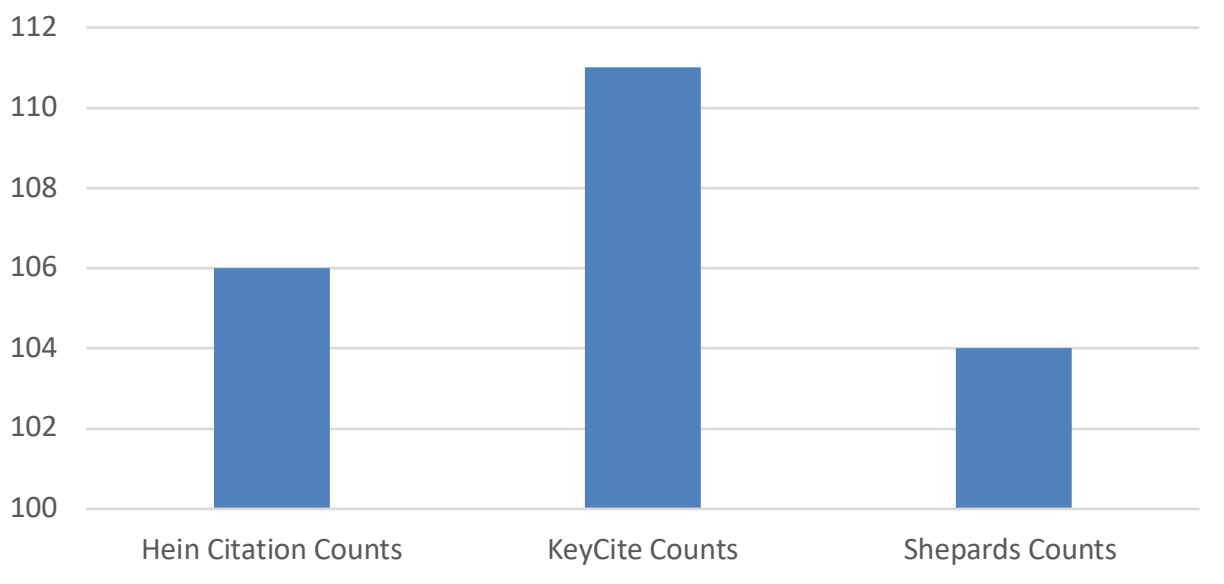


Scholar 5: Total Citations of 24 Works Reported in Each Source

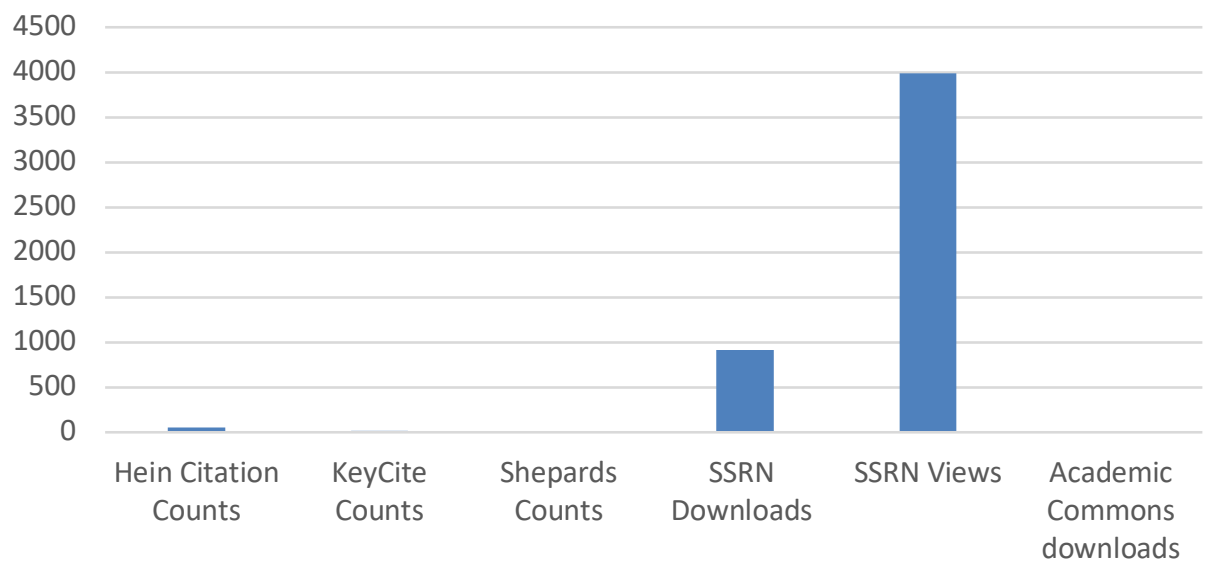

Scholar 5: Hein, KeyCite, Shepard's Comparison of Citations for 24 Works

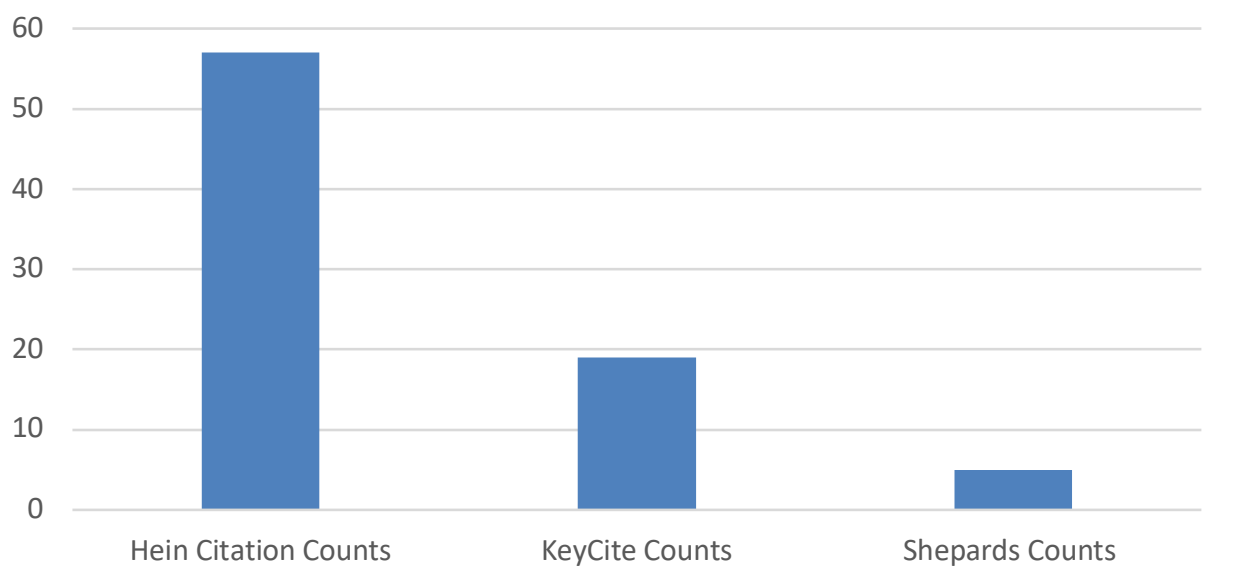


Scholar 6: Total Citations of 33 Works Reported in Each Source

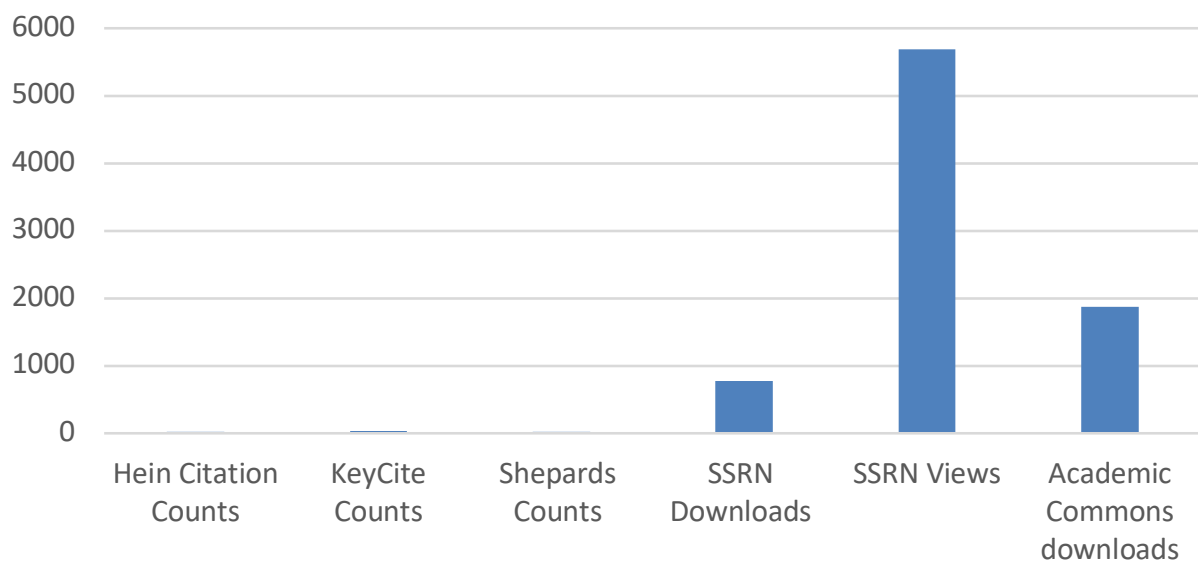

Scholar 6: Hein, KeyCite, Shepard's Comparison of Citations for 33 Works

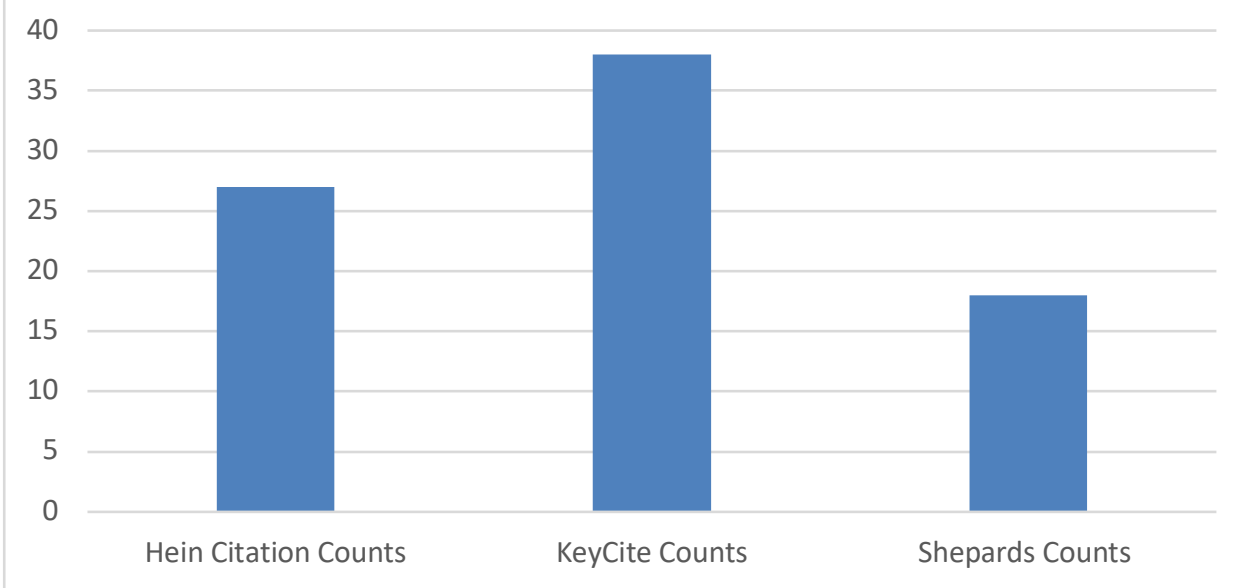


Scholar 7: Total Citations of 7 Works Reported in Each Source

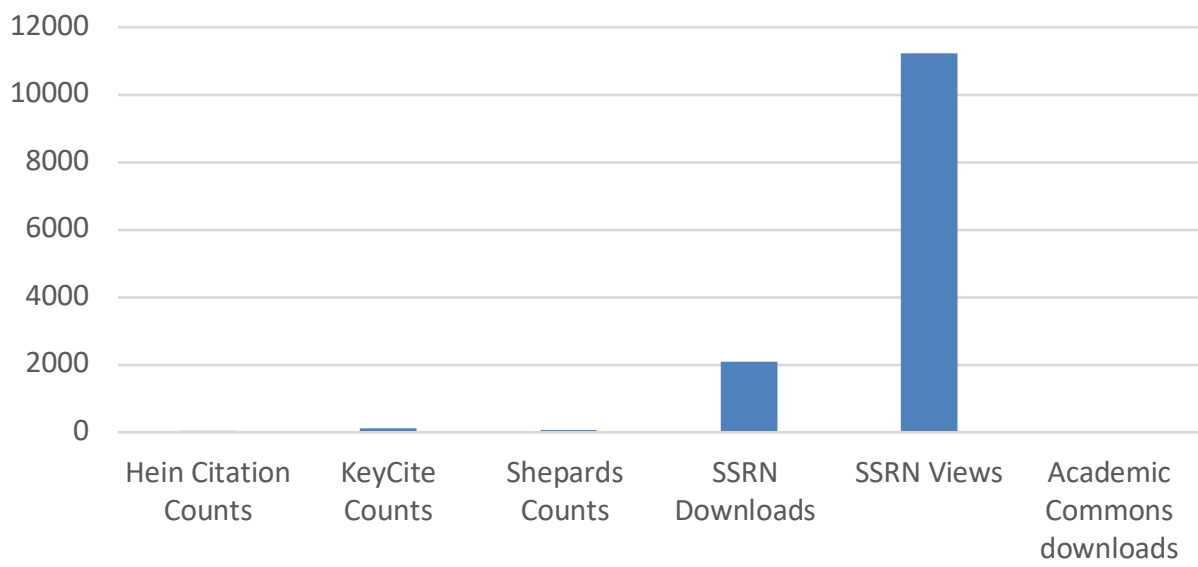

Scholar 7: Hein, KeyCite, Shepard's Comparison of Citations for 7 Works

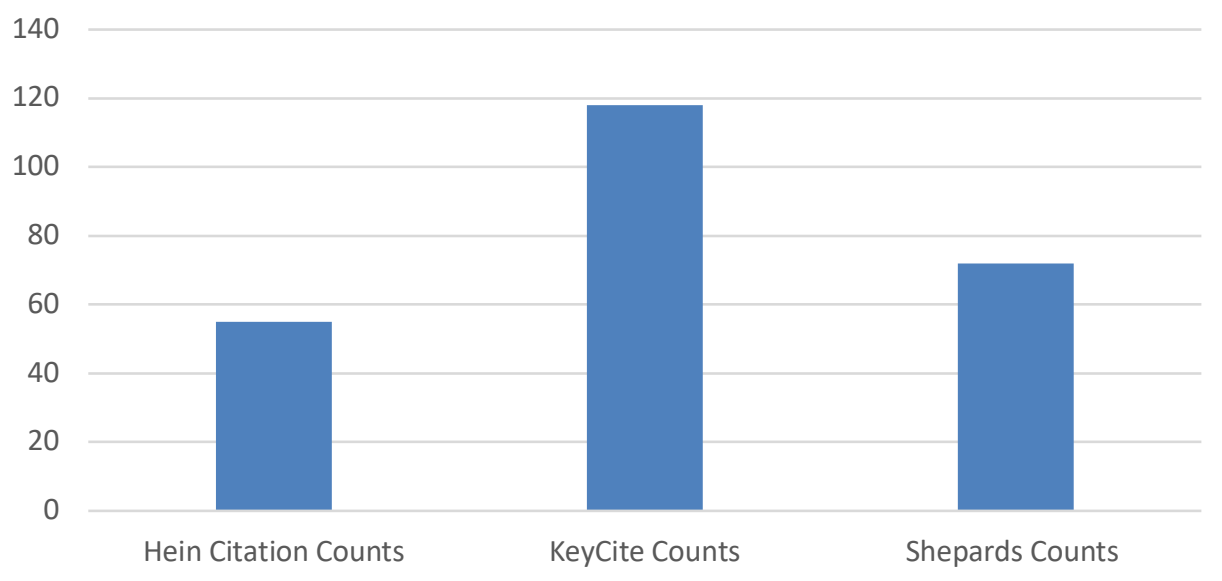


Scholar 8: Total Citations of 8 Works Reported in Each Source

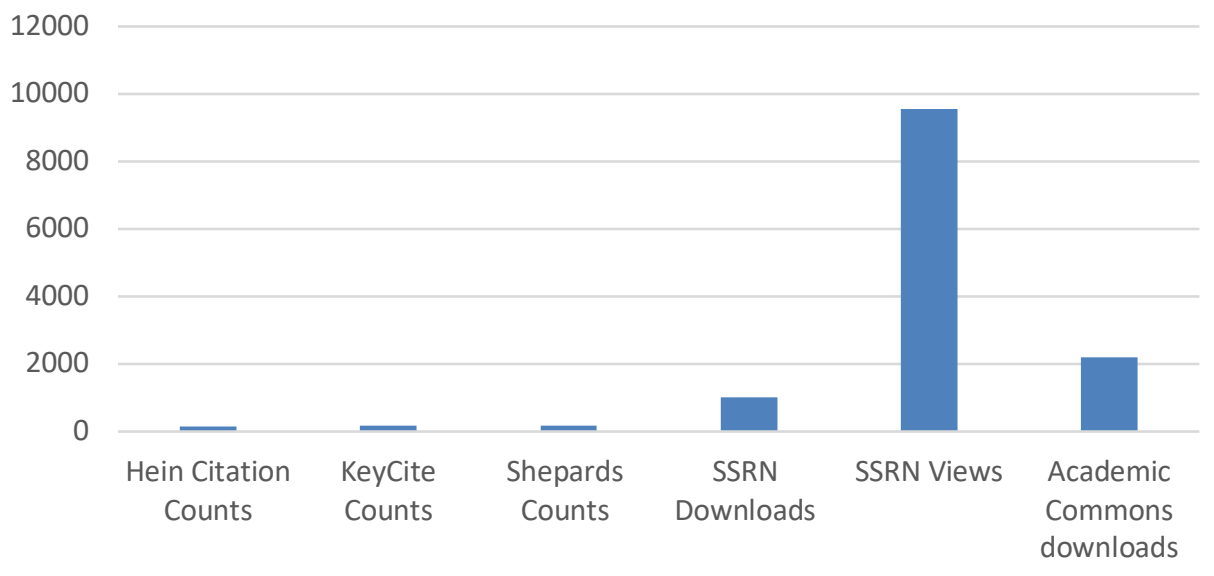

Scholar 8: Hein, KeyCite, Shepard's Comparison of Citations for 8 Works

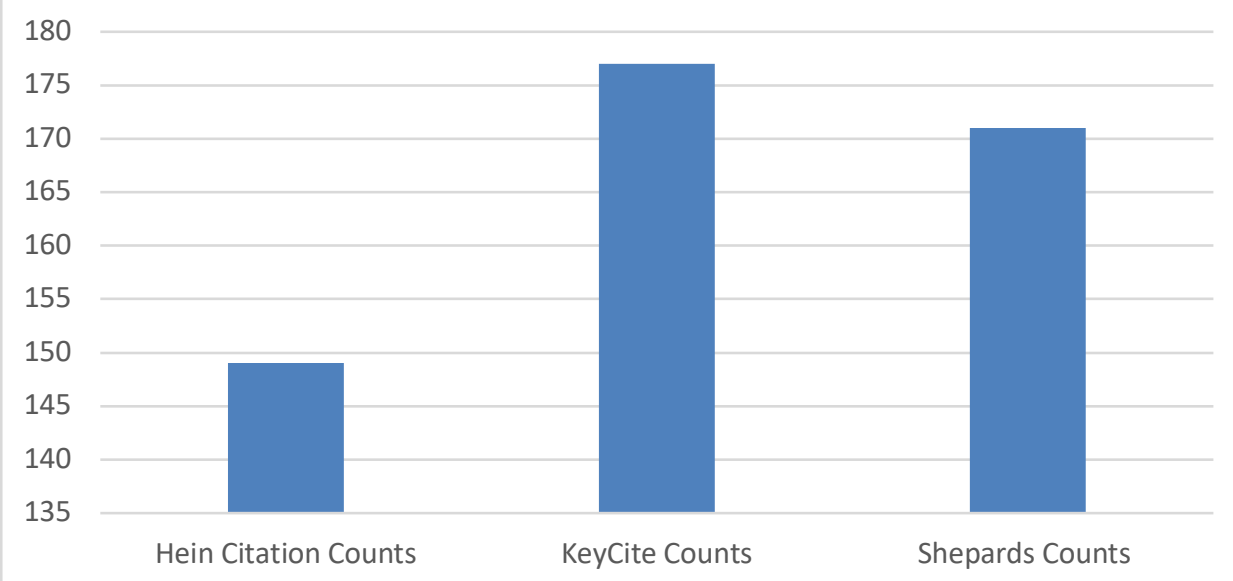

